\title{
From Functional Potential of Soil Bacterial Communities Towards Petroleum Hydrocarbons Bioremediation
}

\author{
Paul Iturbe-Espinoza ${ }^{1} \quad$ Matthijs Bonte $^{2} \quad$ David Brown $^{3} \quad$ Rob JM van Spanning ${ }^{1}$ \\ 1.Department of Molecular Cell Biology, Faculty of Science, Vrije Universiteit Amsterdam, the Netherlands. \\ 2.Shell Global Solutions International, Rijswijk, the Netherlands. \\ 3.Ricardo energy and environment, Harwell, UK \\ * E-mail of the corresponding author: p.iturbeespinoza@vu.nl
}

\begin{abstract}
Molecular ecology researches are rapidly advancing the knowledge of microorganisms associated with petroleum hydrocarbon degradation, one of the major large-scale pollutants in terrestrial ecosystems. The design and monitoring of bioremediation techniques for hydrocarbons rely on a thorough understanding of the diversity of enzymes involved in the processes of hydrocarbon degradation and the microbes that harbor their allocated genes. This review describes the impact of hydrocarbon pollution on soil microbial communities, the state of the art of detecting functional genes, and functional groups. We will focus on i) the structure, function and succession behavior of microbial communities exposed to hydrocarbons, ii) key genes and pathways, iii) future prospect into bioremediation of petroleum hydrocarbons in aerobic environments. The aim is to get a fundamental insight in these issues to ultimately improve petroleum hydrocarbons bioremediation.
\end{abstract}

Keywords: Petroleum hydrocarbons, microbial communities, functional genes, oil degradation, bioremediation. DOI: $10.7176 / \mathrm{JBAH} / 9-10-01$

Publication date:May $31^{\text {st }} 2019$

\section{Introduction}

Petroleum hydrocarbon compounds can impact soil and groundwater mainly due to spills during exploration, production and distribution of oil and gas and derived petroleum products or as a result of natural seepage (Das \& Chandran 2010). Hydrocarbons include a large array of linear, branched, cyclic and aromatic components (Brown et al. 2017) all of which different in terms of volatility, bioavailability, toxicity, degradability, and persistence. Alkanes with carbon chain lengths longer than $\mathrm{C}_{8}$, for instance, can cause hardening and, as a result, limit wetting of soils (Liu et al. 2015). Polycyclic aromatic hydrocarbons (PAHs) are dangerous to human health as they cause mutagenesis and carcinogenesis even at low levels of exposure (Hesham et al. 2014). As a consequence, sixteen PAHs have been listed by the US Environmental Protection Agency as priority contaminants in ecosystems (Habe \& Omori 2003; Keith \& Telliard 1979).

However, biodegradation of hydrocarbons occurs naturally and is found in most types of soils (Pinholt et al. 1979; Whitby \& Skovhus 2009). In fact, microbes which have the potential to degrade hydrocarbons are widely distributed in the environment (Bamforth \& Singleton 2005; Head et al. 2006; Whitby \& Skovhus 2009; Fukuhara et al. 2013; Boon et al. 2014) and exposure to hydrocarbons result in changes in the microbial community structure. During this process, genes encoding for a variety of metabolizing enzyme are critical for the ability of microorganisms to biodegrade hydrocarbons (Liu et al. 2015).

Technologies based on abilities of certain microorganisms to enzymatically degrade petroleum hydrocarbons can often be very effective for remediation because they are minimally invasive, require little disturbance of soils, are often cost-effective and result in minimal secondary contamination (Balba et al. 1998; Das \& Chandran 2010; Fuentes et al. 2014; Wilson \& Jones 1993). Abiotic methods used for the soil remediation such as excavation followed by incineration, soil washing, removal of hydrocarbons by thermal desorption are expensive and can lead to incomplete decomposition of contaminants (Das \& Chandran 2010; Morelli et al. 2013; Thakur 2014). The most promising and energy efficient process for removing petroleum hydrocarbons from soil environments is aerobic bioremediation that can result in the complete mineralization of hydrocarbons (Bailey et al. 1973; Das \& Chandran 2010; Fuentes et al. 2014).

Despite soil microbial communities having great potential for bioremediation of petroleum hydrocarbons and the considerable amount of literature on microbial hydrocarbon degradation, the scientific community is yet to arrive at a consensus on the key bacteria species and molecular mechanisms involved, and how they can contribute to oil bioremediation in polluted soils. Information on community composition of bacteria, their catabolic genes involved in hydrocarbon degradation along with their mutual interactions will enable a more efficient implementation of remedial strategies that rely on monitored natural attenuation as well as remedies that aim at stimulating natural attenuation through addition of nutrients, electron acceptors, and specific microorganisms (Head et al. 2006; Adams et al. 2015).

Previous reviews on the microbiology of hydrocarbon degradation initially emphasized i) the environmental factors that contribute to the biodegradation rate (Leahy \& Colwell 1990), ii) the diversity of alkane oxygenase 
systems (Beilen \& Funhoff 2005; Das \& Chandran 2010; Varjani 2017), iii) the enzymes for aerobic biodegradation of PAHs and their apparent functional redundancies (Fuentes et al. 2014; Head et al. 2006; Vila et al. 2015), and iv) microbial communities modeling approaches for hydrocarbon degradation (Röling et al. 2014a). In spite of all this information, the relationship between a repertoire of genes, encoded enzymes and functional groups existing in a microbial community is still not well understood.

The aim of this review is to organize a guideline of the state of the art of the species composition and genes associated with hydrocarbon degradation in microbial communities, their interactions and succession and, ultimately, how the control of the overall degradation process is divided over different functional groups. To achieve this, three topics will be discussed: i) the succession of soil microbial communities upon hydrocarbon pollution, ii) genes and pathways associated with hydrocarbon biodegradation, iii) future prospect of bioremediation of petroleum hydrocarbons in oxic environments, with an emphasis on soil systems.

\section{Succession of soil microbial communities upon hydrocarbon pollution}

Degradation of petroleum hydrocarbons generally requires evolution of the existing microbial community to a new organizational state that usually constitute a small number of phylotypes with overall broad enzymatic capacities (Bordenave et al. 2007; Hesham et al. 2014; Leahy \& Colwell 1990). Patel et al. (2016) showed that exposure to petroleum hydrocarbons causes a significant reduction on microbial diversity which can be attributed to a combination of hydrocarbon compounds being toxic to some microbes while providing novel types of carbon and free energy sources to other more specialized microbes.

Various researchers have demonstrated that the indigenous microbial communities can adapt within hours, with an increase in hydrocarbon-degrading bacteria along with their hydrocarbon-degrading genes (Atlas \& Bartha 1997; Juck et al. 2000; Kostka et al. 2011; Lindstrom et al. 1999; Röling et al. 2002). Some of the genes involved in catabolism of hydrocarbons are expressed constitutively (Cappelletti et al. 2011; Tani et al. 2001). However most of them are ordered in inducible operons located on chromosomes or plasmids. There are three interconnected mechanisms to start biodegradation. These are i) selective enrichment of organisms able to transform the compounds of interest, ii) induction of specific enzymes in these species, and iii) genetic changes which result in new metabolic capabilities and enhanced rates of growth on oil components (Leahy \& Colwell 1990; MacNaughton et al. 1999; Ogino et al. 2001; Röling, Milner, et al. 2004). Those mechanisms generate a series of successional changes in the structure of the microbial community (Roy et al. 2018). In general terms, Archaea are no longer detected because they are usually hydrocarbon sensitive (Röling et al. 2004), while growth of alkane-degrading specialists sometimes occurs within hours. Following the depletion of alkanes, certain specialists in aromatic hydrocarbon degradation are able to dominate the bacterial community (Habe \& Omori 2003; Head et al. 2006; Röling et al. 2014a). Thereby, hydrocarbon-utilizing bacteria are able to reflect the degree of contamination of the soil using specific catabolic genes markers (Evans et al. 2004; Leahy \& Colwell 1990).

The understanding of the microbial-community dynamics during bioremediation is still in its infancy. Because an individual bacterium can metabolize only a limited range of hydrocarbons (Adams et al. 2015; Chikere et al. 2011; Paniagua-Michel \& Fathepure 2018), the breakdown intermediates can be used by the same bacteria or by other members of the community forming part of a microbial degradation network. The microbial interactions during hydrocarbon degradation involves antagonistic interactions such as competition for limiting nutrients (mostly $\mathrm{N}$ and $\mathrm{P}$ ), antibiotic production by competing organisms, and predation by bacteria, protozoa and bacteriophages (Gentry et al. 2004). The positive interactions include i) production of biosurfactant that reduce the surface tension and disperse hydrocarbons into small droplets (commensalism), ii) cross-feeding or pathway completion where microorganisms are engaged in exchange of metabolites (mutualism) and iii) horizontal gene transfer reported as one of the major mechanisms responsible for the evolution of enhanced hydrocarbon degradation rates (Obayori \& Salam 2010). All those interactions are influenced by the element fluxes of metabolites and nutrients on the one hand and environmental conditions of the spatial-temporal dynamic of the community on the other hand.

The identification of the primary degraders and their catalytic potential as a first critical step in this ecological network is important for understanding, evaluating and developing in situ petroleum hydrocarbons bioremediation strategies.

\section{Genes and pathways associated with aerobic hydrocarbon degradation}

The initial intracellular attack of hydrocarbons involves the activation as well as incorporation of oxygen in an enzymatic key reaction catalyzed by oxygenases. These are usually monooxygenases for breakdown of aliphatic compounds and dioxygenases for that of aromatic compounds. The general pathway is shown in figure 1 . The oxygenases are part of different enzyme systems that are distributed mainly among Proteobacteria, Actinobacteria and Firmicutes (Fuentes et al. 2014; Popp et al. 2006). Alkanes are highly reduced molecules with single bonds that are less difficult to break down. Homocyclic aromatic compounds on the other hand are 
particularly difficult to degrade due to the even distribution of electrons around the aromatic ring which makes them relatively more recalcitrant to reduction or oxidation reactions required for degradation. Thus, hydrocarbons differ in their susceptibility to enzymatic attack according to their chemical reactivity. The easiest ones to degrade are n-alkanes, followed by branched alkanes, low molecular weight aromatic cyclic alkanes and finally high molecular weight aromatics.

\subsection{Alkane-degrading enzymes}

Monooxygenases can catalyze a variety of reactions including the hydroxylation of linear and branched aliphatic, alicyclic, and alkylaromatic compounds (Ji et al. 2013). The aerobic degradation starts by converting alkanes to the corresponding alcohols, aldehydes, carboxylic acids, and acyl-coenzyme A's (CoAs), which then enter the $\beta$ oxidation pathway. Based on the type of cofactor and cellular location, five families of bacterial alkane monooxygenase can be distinguished (Coleman et al. 2011; Torres Pazmiño et al. 2010). These are i) particulate alkane hydroxylases (pAH/AlkB) (Kok et al. 1989; van Beilen et al. 2002), ii) cytochromes P450 (CYP) (Bernhardt 2006; Maier et al. 2001), iii) flavin-dependent monooxygenases (van Berkel et al. 2006; ThroneHolst et al. 2007), iv) particulate copper-containing alkane monooxygenases (pMMO-family) (Lieberman \& Rosenzweig 2004) and v) soluble diiron alkane monooxygenases (sMMO-family) (Leahy et al. 2003; Notomista et al. 2003). A summary of the key genes, composition of enzymes, substrate preferences and hydrocarbon degraders in soils is shown in Table 1.

\subsubsection{Particulate alkane hydroxylases ( $p A H / A l k B$ )}

The particulate (or membrane-associated) non-heme iron alkane hydroxylases oxidize substrates with chain lengths from $\mathrm{C}_{3}$ to $\mathrm{C}_{16}$ (Beilen et al. 2003; Smith et al. 2013). They are encoded by three genes, alkB for the catalytically active alkane hydroxylase, and $a l k G$ and alkT for rubredoxin and rubredoxin reductase, respectively (Cappelletti et al. 2011; Smits et al. 2002; Staijen et al. 2000). The alkane hydroxylase gene (alkB) and its promoter were first identified in Pseudomonas putida (Baptist et al. 1963) where they were shown to be located on a so-called OCT-plasmid (Kok et al. 1989). As such, the gene cluster may well be spread amongst community members via horizontal gene transfer (van Beilen et al. 2001).

The alkB gene sequences contain sufficient conservation for the design of broad-spectrum PCR primers that are used to amplify the $a l k B$ gene from environmental samples as a functional marker for tracking the abundance and diversity of alkane degrading communities in a variety of polluted soils (Gielnik et al. 2019; Kloos et al. 2006; Pérez-de-Mora et al. 2011; Whyte et al. 2002). Those studies showed that richness and diversity of alkB genes was higher in polluted soils compared to unpolluted soils.

3.1.2 Cytochrome P450 (CYP)

The soluble cytochrome P450 alkane hydroxylases constitute a super family of ubiquitous heme-thiolate monooxygenases (Das \& Chandran 2010). Phylogenetic analyses grouped them in more than 100 families (Rojo 2009), only 10-15\% of which are found in bacteria (Beilen \& Funhoff 2005). They incorporate oxygen into alkanes with chain lengths from $\mathrm{C}_{5}$ to $\mathrm{C}_{16}$. Electrons for these reactions are provided by ferredoxins or rubredoxins. Reduction of these iron-sulphur proteins is catalyzed by a ferredoxin reductase that uses NAD(P)H as the initial electron donor.

The first member of this family characterized in bacteria was CYP153A1 from Acinetobacter sp. (Maier et al. 2001). After that discovery, the abundance and expression of the CYP gene in soils was studied in much more detail (Afzal et al. 2011; Arslan et al. 2014; Kubota et al. 2005). Cytochrome P450 alkane hydroxylases have since then been described in members of the Actinobacteria such as Mycobacterium and Rhodococcus as well as in other phyla (van Beilen et al. 2005, 2006; Sekine et al. 2006). Bacteria with CYP genes have great interest since their enzymes are not only involved in alkane hydroxylation but also in dehalogenation of aromatic compounds. As such, they may be exploited for future biotechnological needs in bioremediation of soils polluted with these kinds of compound.

\subsubsection{Flavin-dependent monooxygenases (AlmA and LadA)}

Flavin dependent monooxygenases have either flavin mononucleotide (FMN) or flavin adenine dinucleotide (FAD) as cofactor. These enzymes are relevant for the biodegradation of long chain alkanes. In contrast to cytochrome $\mathrm{P} 450$, genes encoding flavin-dependent monooxygenases are more abundant in prokaryotic genomes (Torres Pazmiño et al. 2010). We will describe two principal enzymes AlmA and LadA, respectively.

$\mathrm{AlmA}$ is an integral membrane enzyme involved in the metabolism of alkanes from $\mathrm{C}_{10}$ to $\mathrm{C}_{32}$, and longer. The enzyme is a member of the subclass of flavin-containing monooxygenase (FMOs) (van Berkel et al. 2006; Ziegler 2002). The almA gene was first identified in Acinetobacter sp. DSM 17874 (Throne-Holst et al. 2007). It was then recognized in many other Acinetobacter species capable of degrading long chain alkanes (Wentzel et al. 2007) as well as in in marine microbes belonging to the genus Pseudomonas, Alcanivorax, Marinobacter, Acinetobacter, Salinisphaera and Parvibaculum (Liu et al. 2011; Wang \& Shao 2012). Little is known about the environmental distribution of this gene type in contaminated soils. The only putative AlmA-like oxygenase reported in contaminated soil is from Pseudomonas aeruginosa (Liu et al. 2014). 
LadA is member of a subclass of bacterial luciferases and can degrade alkanes ranging from $\mathrm{C}_{15}$ to $\mathrm{C}_{36}$ (Feng et al. 2007). The LadA homologue from the soil bacteria Geobacillus thermodenitrificans, is characterized as a thermophilic extracellular and soluble long-chain alkane monooxygenase. The gene LadA, isolated from a deep-subsurface oil reservoir after genome sequencing and confirmed by in vivo and in vitro experiments (Feng et al. 2007), shows no detectable similarity to other alkane oxidizing enzymes from soils or other environments. It is the first long-chain n-alkane monooxygenase to be cloned and structurally characterized (Li et al. 2008). The crystal structure of LadA reveals a two-component flavin-dependent oxygenase with a large hydrophobic pocket to accommodate the FMN cofactor, $\mathrm{O}_{2}$, and terminal parts of a long-chain n-alkane in order to produce primary alcohols (Feng et al. 2007). This thermophilic LadA is an ideal candidate for treatment of environmental oil pollutions and biosynthesis of complex molecules.

3.1.4 Copper-containing enzymes ( $p M M O s$ )

The particulate methane monooxygenase (pMMOs) are found in bacteria that aerobically grow on methane (Torres Pazmiño et al. 2010), but these enzymes also act on alkanes from $\mathrm{C}_{2}$ to $\mathrm{C}_{5}$ as well as on several other hydrophobic compounds (Elliott et al. 1997). An example of these monooxygenases is pMMO from Methylococcus capsulatus whose crystal structure shows three subunits $\alpha, \beta$, and $\gamma$, and three metal-binding centers, two of which are copper centers (mono- and dinuclear, respectively), and the third contains zinc (Balasubramanian et al. 2010; Culpepper \& Rosenzweig 2012; Kitmitto et al. 2005; Lieberman \& Rosenzweig 2005; Smith et al. 2011). The pMMO gene has been used as a phylogenetic marker for identifying methanotroph-specific DNA sequences in soils (Baani \& Liesack 2008; Hoffmann et al. 2002; R \& J.Colin 1997; Roey \& Ralf 2009), but it may identify alkane degrading capacities as well.

3.1.5 Soluble diiron monooxygenases ( $S M M O)$

Another type of MMO is a cytoplasmic diiron monooxygenases (sMMO). They can oxidize alkanes from $\mathrm{C}_{1}$ to $\mathrm{C}_{8}$ as well as a broad range of substrates and as such they are relevant for biodegradation of alkanes and monoaromatic hydrocarbons (Beilen \& Funhoff 2007; Green \& Dalton 1989). Its crystal structure reveals three components: hydroxylase, reductase and a regulatory protein. The hydroxylase component is a dimer with three subunits namely $(\alpha \beta \gamma)_{2}$ (Grosse et al. 1999; Rosenzweig et al. 1993). Structural and functional analysis has revealed that the $\alpha$-subunit contains the catalytic binuclear iron center that is required for the oxidation reaction (Merkx et al. 2001). It turns out that sMMO is less prevalent than pMMO (Rojo 2009). If a strain contains both pMMO and sMMO, expression of sMMO occurs only under conditions of low copper availability (Hakemian \& Rosenzweig 2007; Lieberman \& Rosenzweig 2004).

\subsection{Aromatic hydrocarbons degrading enzymes}

The catabolism of aromatic hydrocarbons in bacteria is extremely diverse and complex because of i) the large variety in PAHs (660 reported by (Reed 2011)), ii) the considerable amount of energy required to change an aromatic compound into a nonaromatic and iii) the number of genes and enzymes involved in the complete breakdown of these compounds. For instance, in Mycobacterium vanbaalenii PYR-1, the degradation of pyrene needs the sequential action of 27 enzymes (Kim et al. 2007). Furthermore, the genetic organization and function of aromatic catabolic genes are still not fully understood since many proposed gene functions need to be assessed experimentally. In addition, the activation of an aromatic hydrocarbon may produce molecules with higher toxicity, leading to persistent products (Lundstedt et al. 2003).

Evidence for biodegradation of high-molecular-weight PAHs, containing more than four aromatic rings such as chrysene, benzo[a]pyrene and benz[a]anthracene is still limited. This is in contrast to the bacterial degradation of monoaromatic compounds and low-molecular-weight PAHs (containing two or three aromatic rings) such as naphthalene, acenaphthene, fluorene, phenanthrene and anthracene, since the biochemical pathways for their breakdown have been well studied and reviewed (Fuentes et al. 2014; Habe \& Omori 2003; Jones et al. 2011; Ladino-Orjuela et al. 2016; Lu et al. 2011; Peng et al. 2008; Seo et al. 2009; Wick et al. 2003). The biodegradation process of these relatively simpler compounds is commonly separated into peripheral and central pathways. Peripheral pathways include the incorporation of molecular oxygen into the aromatic nucleus forming cis-dihydrodiol (Carredano et al. 2000; Ferraro et al. 2006). These compounds are rearomatized through a cis-diol dehydrogenase to yield dehydroxylated intermediates such as catechol, salicylate, gentisate, homogentisate, protocatechuate or phthalate (Fuentes et al. 2014). In the central pathway, the covalent bond of the aromatic ring of these dihydroxylated intermediates are cleaved by enzymes between two adjacent carbon atoms with hydroxyl groups (meta-pathway) or between a carbon with a hydroxyl group and its adjacent carbon with a carboxyl group (ortho-pathway) (Seo et al. 2006), which then are further degraded into TCA cycle intermediates (Cerniglia 1992; Habe \& Omori 2003). Most of the enzymes necessary in the central pathway can be common between community members.

The incorporation of molecular oxygen into an aromatic hydrocarbon is the most difficult yet important catalytic step (Jouanneau et al. 2011). It is catalyzed by a ring hydroxylating oxygenase (RHO) belonging to the family of Rieske non-heme iron oxygenases (Gibson \& Parales 2000) that have been studied in many different 
microorganisms. RHOs are multi-component enzymes consisting of an oxygenase and an electron transport chain. The oxygenase is the catalytic portion composed of large and small subunits ( $\alpha$ and $\beta$, respectively) that are either homo- $(\alpha n)$ or hetero-oligomers $(\alpha n \beta n)$ (Butler \& Mason 1997; Kweon et al. 2008; Parales et al. 1998). The electron transport chain can be a flavoprotein reductase or a flavoprotein reductase and a ferredoxin (Figure 2 ). The electron transport chain transfers reducing equivalents from $\mathrm{NAD}(\mathrm{P}) \mathrm{H}$ to the oxygenase components. Finally, the oxygenase transfers electrons from the electron donor to break down the aromatic hydrocarbon electron acceptor.

To date, over a thousand of RHOs have been identified and compiled in the GenBank as well as in the ring-hydroxylating oxygenase database (Chakraborty et al. 2014). Based on substrate specificities and functional evolutionary behavior of the enzyme components, a classification of RHOs into five type-groups has been proposed (Chakraborty et al. 2012; Kweon et al. 2008; Nam et al. 2001). Type I comprises broad range monooxygenases including monooxygenases like sMMO. The other four types contain typical dioxygenases (RHD). RHOs have low substrate specificity as a common feature (Jouanneau et al. 2011), allowing bacteria to initiate the degradation of a wide range of aromatic hydrocarbons. Type II enzymes such as benzoate and toluate dioxygenases activate the catabolism of heterocyclic compounds. Types III, IV and V include enzyme systems for the activation of aromatic hydrocarbons. Figure 3 summarize the pathways proposed for each type.

3.2.1 Type III naphthalene/PAH dioxygenases

Type III enzymes make part of three-component systems that consist of the oxygenase, a [2Fe-2S]-type ferredoxin and a ferredoxin-NADP ${ }^{+}$reductase (FNR) typically present in Gram negative bacteria. The threedimensional structure of the catalytic component of naphthalene dioxygenase of Pseudomonas sp. NCIB9816-4 (NDO) has been characterized. It have revealed that NDO oxidizes bi- and tri-cyclic PAH substrates, such as naphthalene, phenanthrene and anthracene (Kauppi et al. 1998).

The metabolism of naphthalene has been studied in Pseudomonas putida strain G7. In this strains, the transmissible plasmid coding for naphthalene catabolism was isolated (Dunn \& Gunsalus 1973). This plasmid contains the naphthalene catabolic genes (nah) organized into two operons: upper and lower encoding enzymes for the peripheral and central pathways, respectively. The upper operon nahABFCED encodes six enzymes for the conversion of naphthalene into salicylate (Habe \& Omori 2003). Enzymes encoded by the lower operon nahGTHINLOMKJ transform salicylate via meta-cleavage into pyruvate and acetaldehyde (Simon et al. 1993). Both upper and lower operons are regulated by a trans-acting positive control regulator encoded by the nahR gene, which is sandwiched by the two operons. NahR is needed for high-level expression of the nah genes and their induction by salicylate. In effect, binding of salicylate to NahR at the promoters induces a conformational change in DNA-bound NahR that enables transcription to occurs.

Bacteria with RHD Type III enzymes like Pseudomonas are ubiquitous in soil environments particularly after hydrocarbon pollutions (Ahn et al. 1999; Lloyd-Jones et al. 1999; Martin et al. 2013; Tuomi et al. 2004; Widada et al. 2002). The genetic organization of the naphthalene dioxygenase system present in P. putida resembles those in other different Pseudomonas strains as well as in other Proteobacteria like Comamonas testeroni strain GZ42 (Goyal \& Zylstra 1996), and Burkholderia sp. strain RP007 (Laurie \& Lloyd-Jones 1999). Yet other strains like Ralstonia sp. U2 and Polaromonas naphthalenivorans CJ2 have so-called nag genes to convert naphthalene to gentisate rather than the Pseudomonas-type nah genes where naphthalene is converted in salicylate (Jeon et al. 2006; Zhou et al. 2001). A third group of species, like Alcaligenes faecalis AFK2 and Acidovorax NA3, have phn genes to degrade phenanthrene through protocatechuate with some unique accessory genes (Singleton et al. 2009).

3.2.2 Type IV benzene/toluene/biphenyl dioxygenases

The type IV enzymes make part of yet another three-component system that consist of an oxygenase, a [2Fe-2S]type ferredoxin and a glutathione reductase (GR). This type is the largest group for the known RHD enzyme systems that includes the biphenyl, toluene and PAH metabolic enzymes from both Gram negative and positive bacteria (Takeda et al. 1998). The three dimensional structure of the components of biphenyl dioxygenase from Sphingobium yanoikuyae B1 was characterized (Ferraro et al. 2007; Yu et al. 2007). Later, also those from Sphingomonas CHY-1 (Jakoncic et al. 2007) and Rhodococcus sp. RHA1 were determined (Furusawa et al. 2004). The biphenyl dioxygenase system (BDO) is able to oxidize a broad range of substrates, ranging from one to four-ring PAHs (Ferraro et al. 2007; Kimura et al. 1996; Yu et al. 2007).

The biphenyl biodegradation pathway by the enzymes encoded from the genes bph has been studied in Pseudomonas pseudoalcaligenes KF707 (Furukawa \& Miyazaki 1986) and Burkholderia xenovorans LB400 (Mondello 1989). Typically, the genes bph are located in two clusters. The first cluster called $b p h A B C D$ is common in many aerobic biphenyl degraders and consists of seven genes. Enzymes encoded by this operon are responsible for the transformation of biphenyl into benzoates and aliphatic acids (biphenyl upper pathway). The second cluster of genes is responsible for metabolism of benzoates and aliphatic acids into pyruvate and acetaldehyde via the catechol pathway (Seeger \& Pieper 2010), which can then be further oxidized via the TCA cycle (biphenyl lower pathway). Besides, the biodegradation of monocyclic aromatic hydrocarbon initiated by 
RHD like toluene dioxygenase (TDO) in general follow the similar upper and lower pathways described in this functional group including the catechol pathway.

The diversity and versatility of RHD Type IV enzymes were assessed from different soils contaminated with BTEX and PAH (Cárcer et al. 2007; Furukawa et al. 2004; Seeger \& Pieper 2010). Furthermore, key enzymes in the common pathway, such as catechol 1,2- dioxygenase and catechol 2,3-dioxygenase, were used for detecting biphenyl and toluene metabolic enzymes in soils (Mesarch et al. 2000).

Similar genetic organization of the biphenyl dioxygenase genes described in Burkholderia xenovorans LB400 appear in Ralstonia eutropha H850 (Bedard et al. 1987), Achromobacter xylosoxydans KF701 (Furukawa et al. 1989) Pseudomonas putida KF715 (Hayase et al. 1990) and Burkholderia sp. LB400 (Bartels et al. 1999). Those results could suggest that certain $b p h$ gene clusters were transferred among soil bacteria and have evolved from a common ancestor.

On the other hand, a heterogeneous genetic organization of the biphenyl dioxygenase system is present in Sphingomonads (that includes the genera Sphingomonas, Novosphingobium, Sphingopyxis and Sphingobium) which are able to degrade a wide range of PAHs such as naphthalene, fluorine and phenanthrene because of a large substrate-binding pocket. In Sphingomonads the catalytic genes for breakdown of aromatic hydrocarbons are often localized separately. There is no evident biochemical function of functional operons. All the Sphingomonads genes for degradation of aromatic hydrocarbons are carried on a single plasmid (pNL1) and they encode $\alpha$ and $\beta$ subunits of seven distinct RHOs (Jouanneau et al. 2011; Romine et al. 1999). All these RHOs may receive their electrons from a single set of ferredoxin and ferredoxin reductase. This gives Sphingomonads flexibility and means to adapt easily to new environmental conditions since their RHOs can catalyze the oxidation of many types of aromatic hydrocarbons and simultaneously share the same electron transport chain (Jouanneau et al. 2011; Khara et al. 2014). Therefore, Sphingomonads evolved as an independent subgroup with a possible restriction of gene transfer to other bacteria.

\subsubsection{Type $V$ phthalate/phenanthrene dioxygenases}

Type V enzymes make part of yet other three-component systems that consist of a dioxygenase, a [3Fe-4S]-type ferredoxin and of a glutathione reductase (GR), typically found in Gram positive bacteria. The first well-known example in this group is phenanthrene dioxygenase (encoded by the phdABCD operon) from Nocardioides $s p$. KP7 that transforms phenanthrene to 1-hydroxy-2-naphthoate (Saito et al. 1999). Later on, PhdC was shown to be a novel type of [3Fe-4s]-type ferredoxin as typical electron carrier present in Mycobacterium and Rhodococcus strains (Kweon et al. 2008).

The ability of the genus Mycobacterium to degrade different types of high molecular weight PAHs, including pyrene, fluoranthene, and benzo[a]pyrene has been documented (Cheung \& Kinkle 2001; Kim et al. 2005; Schneider et al. 1996). In Mycobacterium PYR-1, the genes encoding the hydroxylase component of a pyrene dioxygenase were first called nidBA (nid for naphthalene induced) (Khan et al., 2001). Based on system biology analysis of genomic and proteomic data, 27 enzymes were identified to be necessary for constructing a complete pathway for pyrene degradation to central intermediates through o-phthalate and the $\beta$-ketoadipate pathway in $M$. vanbaalenii PYR-1, (Kim et al. 2007). In another pyrene degrader Mycobacterium 6PY1, a thorough proteomic analysis of pyrene- and phenanthrene-induced polypeptides identified 23 proteins, four of which were subunits of two gram-positive RHDs named Pdo1 and Pdo2 (Krivobok et al. 2003). Amino acid sequence comparison indicated that Pdo1 and Pdo2 are similar to the pyrene dioxygenase from strain PYR-1, and phenanthrene dioxygenase from strain KP7, respectively (Krivobok et al., 2003). Additionally, Other Mycobacterium strains able to degrade pyrene or fluoranthene were found to express RHDs homologous to Pdo1 or Pdo2 (Kim et al. 2005; Roey \& Ralf 2009; Seo et al. 2006).

Multiple pathways of pyrene degradation operate in Mycobacterium vanbaalenii PYR 1 strain (Brezna et al. 2006; Heitkamp \& Cerniglia 1988). The general pathway of pyrene degradation is dioxygenation at the 4,5positions to produce trans-4,5-pyrenedihydrodiol. Rearomatization of the dihydrodiol and subsequent orthocleavage lead to the formation of 4,5-dicarboxyphenanthrene, which is further decarboxylated to 4phenanthroate. Following another dioxygenation reaction, 4-phenanthroate forms cis-3,4dihydroxyphenanthrene-4-carboxylate. Rearomatization of the metabolite yields 3,4-dihydroxyphenanthrene, which is further metabolized to 1-hydroxy-2-naphthoate. The subsequent enzymatic reactions, including intradiol ring cleavage dioxygenation, result in the production of $o$-phthalate. Then phthalate is further metabolized via the $\beta$-ketoadipate pathway and via the TCA cycle, successively (Kim et al. 2003; Wang et al. 2000).

RHD genes from Mycobacterium and Rhodococcus were reported in soil environments by (Debruyn et al. 2009; Hall et al. 2005; Marcos et al. 2009; Peng et al. 2010; Ren et al. 2015; Shahsavari et al. 2016). Therefore, the abundance of nidA gene serves as a biomarker for pyrene and other PAH degradation processes. The prevalence of Mycobacterium nidA genotypes corroborated previous studies indicating that PAH-degrading Mycobacteria have a cosmopolitan distribution and suggests they play an important role in natural attenuation of PAHs. 


\subsection{Conclusion}

Although none of the enzyme systems is completely specific, a broad correlation between the grouping in alkanes and aromatics-degrading enzymes subfamilies and the native substrates oxidized by the subfamily members can be perceived. It is unlikely that PCR primers that were used to genotype particular environments will reliably cover the huge diversity of homologous genes within each sub-group. Besides the first catalytic steps that lead the degradation pathways, the complete metabolism of hydrocarbons depends upon the collective activities of peripheral and central pathway enzymes. We may then conclude that diversity of hydrocarbonsdegrading genes and enzymes is unexpectedly high, which may support the hypothesis that natural attenuation of petroleum hydrocarbons occurs widely in nature by functional redundancies in enzymes that overlap in substrates and metabolites. The full range of genes involved, their genetic regulation and organization as well as the interaction of all those enzymes in the microbial degradation network is still far from being understood. Therefore, the application of omics approaches is crucial to study the functional potential of microbial communities that we are going to discuss in the next section.

\section{Future prospect into bioremediation of petroleum hydrocarbons in soils}

Traditional analytical chemistry and molecular tools have identified individual functional genes, metabolic pathways and key players. For example, culturable bacteria such as Pseudomonas, Sphingobium and Acinetobacter have been isolated and provide suitable, tractable systems to perform controlled biodegradation experiments (Röling et al. 2014a). Genome and transcriptome sequencing of these organisms have been carried out. Databases such as GenBank and Uniprot support sequencing query and are applied for prediction of gene function of unknown key-players. However, the catabolic machinery of a complex microbial community is still far from being completely understood. The recent applications of cultivation-independent methods such as molecular meta-omics technologies (e.g. meta-barcoding, genomics, transcriptomics, proteomics and environmental metabolomics) can provide a deeper insight into the active microbial processes during hydrocarbon degradation in soils. The implementation of culture-independent methods enables further exploration of the environmental diversity of PAH-degrading bacteria as well as of alkane-degrading enzymes and RHOs.

\subsection{Metabarcoding and metagenomics}

Next-generation sequencing of DNA has revolutionized the study of microbial communities. Metabarcoding, a technology based on the amplicon sequencing of 16S rRNA gene, enabled studying the structure and diversity of microbial communities and may create predictive models in hydrocarbon contaminated soils (Fowler et al. 2016; Jiao et al. 2016; Yang et al. 2016). The output of metabarcoding analysis is a table containing the relative abundance of each Operational Taxonomic Unit (OTU), which represent species abundances (16S reads) in a community sample. Using statistical and network analysis-based tools, it is possible to compute the correlation coefficients among species abundances (Ma et al. 2016). In this way we may identify bacterial interactions (based on correlation) that possibly drive hydrocarbon degradation. This technology can also be applied to specific catabolic genes markers in a targeted functional gene analysis.

Metagenomics, a technology based on shotgun sequencing, allows the study of total genomes from a microbial community. The assemblage of functional groups is essential to predict for example pathways that mediate key reactions in the hydrocarbon biodegradation process (Duarte et al. 2017; Sharpton 2014). Metabarcoding and metagenomics analyses can be combined with targeted functional gene analyses to characterize the metabolic potential of uncultured organisms. This new technology uses labelled ${ }^{13} \mathrm{C}$ hydrocarbons that can be assimilated into cellular biomass (e. g. heavy DNA) of hydrocarbon-degrading bacteria. The resulting labeled DNA is amplified by PCR using stable isotope probing (DNA-SIP) for further metabarcoding or metagenomics sequencing to retrieve the genomes of uncultured hydrocarbon degraders (Grob et al. 2015). Similar SIP based technologies are starting to be applied to characterize RNA (Lueders 2015) and proteins (Bergen et al. 2013).

\subsection{Metatranscriptomics}

A limitation of genetic profiling of hydrocarbon degradation is that genes can be present but not expressed. Metagenomics coupled with metatranscriptomics allows elucidation of the active metabolic processes by quantification of gene expression in an existing microbial community. Only a few metatranscriptomics studies have been applied in hydrocarbon degradation in soils and sediments so far (Gonzalez et al. 2015; de Menezes et al. 2012; Reid et al. 2018). The studies show increases in RHO gene expression and widespread changes in the microbial community structure of soils contaminated with phenanthrene. (Gonzalez et al. 2015) found Bacillus and Klebsiella in greater abundance in trees cultivated on hydrocarbon contaminated soil. (Reid et al. 2018) observed abundance of alkane-degrading and RHO gene expression that suggest considerable natural degradation in hydrocarbon rich sediments. Although most of the dominant species were unclassified, which 
revealed novel lineages of microbes potentially involved in hydrocarbon degradation. Furthermore, highly expressed sequences in their metatranscriptomic data encode proteins with still unknown function. In effect, metatranscriptomics requires mapping of expressed sequences to reference genomes but if absent they remain unexplored and vice versa (González et al. 2016; Hanson et al. 2009). Therefore, it is better to focus on the complete metatranscriptome of an environmental sample with the hypothesis that they serve as genetic fingerprints for contamination by hydrocarbons (Pérez-Pantoja \& Tamames 2015). Consequently, processing data collected from metatranscriptomics studies may well lead to prediction of novel genes important for the degradation of hydrocarbons.

\subsection{Metaproteomics}

While proteomics has been stablished as a robust and reliable technique to study the functional network in single organisms, metaproteomics can be used to understand complex community interactions associated with in situ bioremediation of soil, but it is still in its infancy (Siggins et al. 2012). Metaproteomics analyses involves sample preparation, high throughput mass spectrometry analysis and bioinformatics data processing (Christie-Oleza et al. 2015). Current bottlenecks for this technology applied to contaminated soils include: the lack of complete genome data for all the bacteria, the difficulty in assigning peptides that are highly conserved, the complexity of the peptide mixture, the size of mass spectrometer data generated, and the purification of proteins from contaminated soils that contain interfering humic acids. As a result, there is a small subset of the diversity of proteins expected in soils (Williams et al. 2010). Metaproteomics in combination with protein-stable isotope probing revealed enzymes for the naphthalene degradation pathway in laboratory microcosm that fail in situ (Herbst et al. 2013).

\subsection{Environmental metabolomics}

In contrast to proteomics, metabolomics focuses on identification of metabolites and serve to predict enzymatic activity in an individual organism. These findings may then be extrapolated to environmental metabolomics at the community level to study the functional potential of soils. The microbial degradation of a complex hydrocarbon mixtures generates mixture of oxygenated metabolites which are relatively difficult to detect. The identification of hydrocarbons metabolites require gas chromatography coupled with mass spectrometry and can be theoretically divided in targeted and untargeted approaches (Bonifay et al. 2016). Targeted analyses focus on a specific small number of compounds that are diagnostic for a particular pathway and the original substrate can be identified by the initial activation of the hydrocarbon by the oxygenase. In contrast, an untargeted metabolic analysis qualitatively measures generally unknown metabolites that result from all catabolic pathways in the microbial community (Bargiela et al. 2015). Unraveling such a metabolic fingerprint aimed at the identification of combined catabolic pathways is challenging and may not even be practically achievable.

\subsection{Systems biology modelling approaches}

Mathematical approaches are needed to get a more fundamental understanding of how microbial communities function (Succurro \& Ebenhöh 2018; Wade et al. 2016; Xiao et al. 2017). Systems biology can integrate information on genes, transcripts, proteins, and interacting biological networks in single cells. This approach may be extended to populations and communities in order to characterize a community phenotype. Figure 4 is a scheme that connects different omics approaches in hydrocarbon degradation the integration of which is carried out with modelling approaches. For example, Ecological Regulation Analysis (ERA), is a systems biology approach that quantifies fluxes through a microbial network at the level of individual species or functional groups. Data on cells numbers of species and fluxes through those cells (e.g. substrate consumption, product formation or respiration) in at least two different (near) steady-state conditions enables the calculation of regulation coefficients of each individual species or functional groups (Röling et al. 2014b).

Metabolic flux models investigate the functional and microbial capacity either in top-down or in bottom-up approaches. The top-down approach focuses on ecological significances of microbial community, where the species provide the building blocks for the model. They include interaction of species and metabolites, but they lack details at the gene level. Conversely, the bottom-up approach focuses on metabolic pathways and biochemical interactions of the entire community. Those models may provide a high level of prediction, but its complexity is extremely challenging.

\section{Final remarks}

Although decades of microbial research into hydrocarbon degradation processes have generated a comprehensive overview of which hydrocarbons can be biodegraded and which bacteria and genes are involved, there are still many gaps in our understanding about the main drivers for degradation of hydrocarbons by the microbial communities. Despite novel emerging technologies, it is still difficult to develop a comprehensive understanding on sites contaminated by hydrocarbons whether which microbes are essential and how to enhance 
the biodegradation.

Based on the present review, it may be concluded that the microbial communities play a critical role in the cleaning up process of oil spills in soils. In order to effectively monitor, manage or stimulate a remedial strategy that relies on biodegradation three aspects remain essential: i) to reveal the dynamics and interaction of the indigenous microbial communities, ii) to detect functional metabolic capabilities to monitor and optimize bioremediation and iii) to provide appropriate environmental conditions. Consequently, further research is required to enhance these new technologies to elucidate the metabolic potential and interaction between nonculturable bacteria specialist in hydrocarbon degradation.

\section{Acknowledgments}

This research was funded by FONDECYT-CONCYTEC (216-2015-FONDECYT)

\section{References}

Adams, G. O., Fufeyin, P. T., Okoro, S. E., and Ehinomen, I. (2015). "Bioremediation, Biostimulation and Bioaugmention: A Review," International Journal of Environmental Bioremediation \& Biodegradation, 3(1), 28-39. DOI: 10.12691/ijebb-3-1-5

Afzal, M., Yousaf, S., Reichenauer, T. G., Kuffner, M., \& Sessitsch, A. (2011). "Soil type affects plant colonization, activity and catabolic gene expression of inoculated bacterial strains during phytoremediation of diesel," Journal of Hazardous Materials, 186(2), 1568-1575. DOI: 10.1016/j.jhazmat.2010.12.040

Aguiar-Pulido, V., Huang, W., Suarez-Ulloa, V., Cickovski, T., Mathee, K., \& Narasimhan, G. (2016). "Metagenomics, Metatranscriptomics, and Metabolomics Approaches for Microbiome Analysis," Evolutionary Bioinformatics Online, 12(Suppl 1), 5-16. DOI: 10.4137/EBO.S36436

Ahn, Y., Sanseverino, J., \& Sayler, G. S. (1999). "Analyses of polycyclic aromatic hydrocarbon-degrading bacteria isolated from contaminated soils," Biodegradation, 10(2), 149-157.

Arslan, M., Afzal, M., Amin, I., Iqbal, S., \& Khan, Q. M. (2014). "Nutrients Can Enhance the Abundance and Expression of Alkane Hydroxylase CYP153 Gene in the Rhizosphere of Ryegrass Planted in HydrocarbonPolluted Soil," PLOS ONE, 9(10), e111208. DOI: 10.1371/journal.pone.0111208

Atlas, R. M. (1981). "Microbial degradation of petroleum hydrocarbons: an environmental perspective.," Microbiological Reviews, 45(1), 180-209.

Atlas, R. M., \& Bartha, R. (1997). Microbial Ecology: Fundamentals and Applications, Benjamin Cummings, Menlo Park, Calif.

Baani, M., \& Liesack, W. (2008). "Two isozymes of particulate methane monooxygenase with different methane oxidation kinetics are found in Methylocystis sp. strain SC2," Proceedings of the National Academy of Sciences of the United States of America, 105(29), 10203-10208. DOI: 10.1073/pnas.0702643105

Bailey, N. J. L., Jobson, A. M., \& Rogers, M. A. (1973). "Bacterial degradation of crude oil: Comparison of field and experimental data," Chemical Geology, 11(3), 203-221. DOI: 10.1016/0009-2541(73)90017-X

Balasubramanian, R., Smith, S. M., Rawat, S., Yatsunyk, L. A., Stemmler, T. L., \& Rosenzweig, A. C. (2010). "Oxidation of methane by a biological dicopper centre," Nature, 465(7294), 115-119. DOI: 10.1038/nature08992

Balba, M. T., Al-Awadhi, N., \& Al-Daher, R. (1998). "Bioremediation of oil-contaminated soil: microbiological methods for feasibility assessment and field evaluation," Journal of Microbiological Methods, 32(2), 155164. DOI: 10.1016/S0167-7012(98)00020-7

Bamforth, S. M., \& Singleton, I. (2005). "Bioremediation of polycyclic aromatic hydrocarbons: current knowledge and future directions," Journal of Chemical Technology \& Biotechnology, 80(7), 723-736. DOI: $10.1002 /$ jctb. 1276

Baptist, J. N., Gholson, R. K., \& Coon, M. J. (1963). "Hydrocarbon oxidation by a bacterial enzyme system," Biochimica et Biophysica Acta, 69, 40-47. DOI: 10.1016/0006-3002(63)91223-X

Bargiela, R., Herbst, F.-A., Martínez-Martínez, M., Seifert, J., Rojo, D., Cappello, S., Genovese, M., Crisafi, F., Denaro, R., Chernikova, T. N., Barbas, C., Bergen, M. von, Yakimov, M. M., Ferrer, M., \& Golyshin, P. N. (2015). "Metaproteomics and metabolomics analyses of chronically petroleum-polluted sites reveal the importance of general anaerobic processes uncoupled with degradation," Proteomics, 15(20), 3508-3520. DOI: $10.1002 /$ pmic.201400614

Bartels, F., Backhaus, S., Moore, E. R. B., Timmis, K. N., \& Hofer, B. (1999). “Occurrence and expression of glutathione-S-transferase-encoding bphK genes in Burkholderia sp. strain LB400 and other biphenylutilizing bacteria," Microbiology, 145(10), 2821-2834. DOI: 10.1099/00221287-145-10-2821

Bedard, D. L., Haberl, M. L., May, R. J., \& Brennan, M. J. (1987). "Evidence for novel mechanisms of polychlorinated biphenyl metabolism in Alcaligenes eutrophus H850.," Applied and Environmental Microbiology, 53(5), 1103-1112.

Beilen, J. B. V., Li, Z., Duetz, W. A., Smits, T. H. M., \& Witholt, B. (2003). "Diversity of Alkane Hydroxylase 
Systems in the Environment," Oil \& Gas Science and Technology, 58(4), 427-440. DOI: 10.2516/ogst:2003026

Beilen, J. B. van, \& Funhoff, E. G. (2005). "Expanding the alkane oxygenase toolbox: new enzymes and applications," Current Opinion in Biotechnology, Environmental biotechnology/Systems biology, 16(3), 308-314. DOI: 10.1016/j.copbio.2005.04.005

Beilen, J. B. van, \& Funhoff, E. G. (2007). "Alkane hydroxylases involved in microbial alkane degradation," Applied Microbiology and Biotechnology, 74(1), 13-21. DOI: 10.1007/s00253-006-0748-0

van Beilen, J. B., Funhoff, E. G., van Loon, A., Just, A., Kaysser, L., Bouza, M., Holtackers, R., Röthlisberger, M., Li, Z., \& Witholt, B. (2006). "Cytochrome P450 alkane hydroxylases of the CYP153 family are common in alkane-degrading eubacteria lacking integral membrane alkane hydroxylases," Applied and Environmental Microbiology, 72(1), 59-65. DOI: 10.1128/AEM.72.1.59-65.2006

van Beilen, J. B., Holtackers, R., Lüscher, D., Bauer, U., Witholt, B., \& Duetz, W. A. (2005). "Biocatalytic production of perillyl alcohol from limonene by using a novel Mycobacterium sp. cytochrome P450 alkane hydroxylase expressed in Pseudomonas putida," Applied and Environmental Microbiology, 71(4), 17371744. DOI: 10.1128/AEM.71.4.1737-1744.2005

van Beilen, J. B., Panke, S., Lucchini, S., Franchini, A. G., Röthlisberger, M., \& Witholt, B. (2001). "Analysis of Pseudomonas putida alkane-degradation gene clusters and flanking insertion sequences: evolution and regulation of the alk genes," Microbiology, 147(6), 1621-1630. DOI: 10.1099/00221287-147-6-1621

van Beilen, J. B., Smits, T. H. M., Whyte, L. G., Schorcht, S., Röthlisberger, M., Plaggemeier, T., Engesser, K.H., \& Witholt, B. (2002). "Alkane hydroxylase homologues in Gram-positive strains," Environmental Microbiology, 4(11), 676-682.

Bergen, M. von, Jehmlich, N., Taubert, M., Vogt, C., Bastida, F., Herbst, F.-A., Schmidt, F., Richnow, H.-H., \& Seifert, J. (2013). "Insights from quantitative metaproteomics and protein-stable isotope probing into microbial ecology," The ISME Journal, 7(10), 1877-1885. DOI: 10.1038/ismej.2013.78

van Berkel, W. J. H., Kamerbeek, N. M., \& Fraaije, M. W. (2006). "Flavoprotein monooxygenases, a diverse class of oxidative biocatalysts," Journal of Biotechnology, 124(4), 670-689. DOI: 10.1016/j.jbiotec.2006.03.044

Bernhardt, R. (2006). “Cytochromes P450 as versatile biocatalysts,” Journal of Biotechnology, 124(1), $128-145$. DOI: $10.1016 /$ j.jbiotec.2006.01.026

Bonifay, V., Aydin, E., Aktas, D. F., Sunner, J., \& Suflita, J. M. (2016). "Metabolic Profiling and Metabolomic Procedures for Investigating the Biodegradation of Hydrocarbons," in: Hydrocarbon and Lipid Microbiology Protocols, Springer Protocols Handbooks, Springer, Berlin, Heidelberg, 111-161. DOI: $10.1007 / 8623$ 2016_225

Boon, E., Meehan, C. J., Whidden, C., Wong, D. H.-J., Langille, M. G., \& Beiko, R. G. (2014). "Interactions in the microbiome: communities of organisms and communities of genes," Fems Microbiology Reviews, 38(1), 90-118. DOI: 10.1111/1574-6976.12035

Bordenave, S., Goñi-Urriza, M. S., Caumette, P., \& Duran, R. (2007). "Effects of Heavy Fuel Oil on the Bacterial Community Structure of a Pristine Microbial Mat," Applied and Environmental Microbiology, 73(19), 6089-6097. DOI: 10.1128/AEM.01352-07

Brezna, B., Kweon, O., Stingley, R. L., Freeman, J. P., Khan, A. A., Polek, B., Jones, R. C., and Cerniglia, C. E. (2006). "Molecular characterization of cytochrome P450 genes in the polycyclic aromatic hydrocarbon degrading Mycobacterium vanbaalenii PYR-1," Applied Microbiology and Biotechnology, 71(4), 522-532. DOI: $10.1007 / \mathrm{s} 00253-005-0190-8$

Brown, D. M., Bonte, M., Gill, R., Dawick, J., \& Boogaard, P. J. (2017). "Heavy hydrocarbon fate and transport in the environment," Quarterly Journal of Engineering Geology and Hydrogeology, 50(3), 333-346. DOI: 10.1144/qjegh2016-142

Butler, C. S., \& Mason, J. R. (1997). "Structure-function analysis of the bacterial aromatic ring-hydroxylating dioxygenases," Advances in Microbial Physiology, 38, 47-84.

Cappelletti, M., Fedi, S., Frascari, D., Ohtake, H., Turner, R. J., \& Zannoni, D. (2011). “Analyses of both the alkB gene transcriptional start site and alkB promoter-inducing properties of Rhodococcus sp. strain BCP1 grown on n-alkanes," Applied and Environmental Microbiology, 77(5), 1619-1627. DOI: 10.1128/AEM.01987-10

Cárcer, D. A. de, Martín, M., Karlson, U., \& Rivilla, R. (2007). "Changes in Bacterial Populations and in Biphenyl Dioxygenase Gene Diversity in a Polychlorinated Biphenyl-Polluted Soil after Introduction of Willow Trees for Rhizoremediation," Appl. Environ. Microbiol., 73(19), 6224-6232. DOI: 10.1128/AEM.01254-07

Carredano, E., Karlsson, A., Kauppi, B., Choudhury, D., Parales, R. E., Parales, J. V., Lee, K., Gibson, D. T., Eklund, H., \& Ramaswamy, S. (2000). "Substrate binding site of naphthalene 1,2-dioxygenase: functional implications of indole binding," Journal of Molecular Biology, 296(2), 701-712. DOI: 
10.1006/jmbi.1999.3462

Cerniglia, C. E. (1992). "Biodegradation of polycyclic aromatic hydrocarbons," Biodegradation, 3(2-3), 351368. DOI: 10.1007/BF00129093

Chakraborty, J., Ghosal, D., Dutta, A., \& Dutta, T. K. (2012). "An insight into the origin and functional evolution of bacterial aromatic ring-hydroxylating oxygenases," Journal of Biomolecular Structure \& Dynamics, 30(4), 419-436. DOI: 10.1080/07391102.2012.682208

Chakraborty, J., Jana, T., Saha, S., \& Dutta, T. K. (2014). "Ring-Hydroxylating Oxygenase database: a database of bacterial aromatic ring-hydroxylating oxygenases in the management of bioremediation and biocatalysis of aromatic compounds," Environmental Microbiology Reports, 6(5), 519-523. DOI: 10.1111/17582229.12182

Cheung, P.-Y., \& Kinkle, B. K. (2001). "Mycobacterium Diversity and Pyrene Mineralization in PetroleumContaminated Soils," Applied and Environmental Microbiology, 67(5), 2222-2229. DOI: 10.1128/AEM.67.5.2222-2229.2001

Chikere, C. B., Okpokwasili, G. C., \& Chikere, B. O. (2011). "Monitoring of microbial hydrocarbon remediation in the soil," 3 Biotech, 1(3), 117-138. DOI: 10.1007/s13205-011-0014-8

Christie-Oleza, J. A., Sousoni, D., Armengaud, J., Wellington, E. M., \& Jones, A. M. E. (2015). "Defining a Pipeline for Metaproteomic Analyses," in: Hydrocarbon and Lipid Microbiology Protocols, Springer Protocols Handbooks, Springer, Berlin, Heidelberg, 99-110. DOI: 10.1007/8623_2015_130

Coleman, N. V., Yau, S., Wilson, N. L., Nolan, L. M., Migocki, M. D., Ly, M., Crossett, B., \& Holmes, A. J. (2011). "Untangling the multiple monooxygenases of Mycobacterium chubuense strain NBB4, a versatile hydrocarbon degrader," Environmental Microbiology Reports, 3(3), 297-307. DOI: 10.1111/j.17582229.2010.00225.x

Culpepper, M. A., \& Rosenzweig, A. C. (2012). "Architecture and active site of particulate methane monooxygenase," Critical reviews in biochemistry and molecular biology, 47(6), 483-492. DOI: $10.3109 / 10409238.2012 .697865$

Das, N., \& Chandran, P. (2010). "Microbial Degradation of Petroleum Hydrocarbon Contaminants: An Overview," Biotechnology Research International, 2011, e941810. DOI: 10.4061/2011/941810

Debruyn, J. M., Mead, T. J., Wilhelm, S. W., \& Sayler, G. S. (2009). "PAH biodegradative genotypes in Lake Erie sediments: evidence for broad geographical distribution of pyrene-degrading mycobacteria," Environmental Science \& Technology, 43(10), 3467-3473.

Duarte, M., Nielsen, A., Camarinha-Silva, A., Vilchez-Vargas, R., Bruls, T., Wos-Oxley, M. L., Jauregui, R., \& Pieper, D. H. (2017). "Functional soil metagenomics: elucidation of polycyclic aromatic hydrocarbon degradation potential following 12 years of in situ bioremediation," Environmental Microbiology, 19(8), 2992-3011. DOI: 10.1111/1462-2920.13756

Dunn, N. W., \& Gunsalus, I. C. (1973). "Transmissible plasmid coding early enzymes of naphthalene oxidation in Pseudomonas putida," Journal of Bacteriology, 114(3), 974-979.

Elliott, S. J., Zhu, M., Tso, L., Nguyen, H.-H. T., Yip, J. H.-K., \& Chan, S. I. (1997). "Regio- and Stereoselectivity of Particulate Methane Monooxygenase from Methylococcus capsulatus (Bath)," Journal of the American Chemical Society, 119(42), 9949-9955. DOI: 10.1021/ja971049g

Evans, F. F., Rosado, A. S., Sebastián, G. V., Casella, R., Machado, P. L. O. A., Holmström, C., Kjelleberg, S., van Elsas, J. D., \& Seldin, L. (2004). "Impact of oil contamination and biostimulation on the diversity of indigenous bacterial communities in soil microcosms," FEMS Microbiology Ecology, 49(2), 295-305. DOI: 10.1016/j.femsec.2004.04.007

Feng, L., Wang, W., Cheng, J., Ren, Y., Zhao, G., Gao, C., Tang, Y., Liu, X., Han, W., Peng, X., Liu, R., \& Wang, L. (2007). "Genome and proteome of long-chain alkane degrading Geobacillus thermodenitrificans NG80-2 isolated from a deep-subsurface oil reservoir," Proceedings of the National Academy of Sciences of the United States of America, 104(13), 5602-5607. DOI: 10.1073/pnas.0609650104

Ferraro, D. J., Brown, E. N., Yu, C.-L., Parales, R. E., Gibson, D. T., \& Ramaswamy, S. (2007). "Structural investigations of the ferredoxin and terminal oxygenase components of the biphenyl 2,3-dioxygenase from Sphingobium yanoikuyae B1,” BMC Structural Biology, 7, 10. DOI: 10.1186/1472-6807-7-10

Ferraro, D. J., Gakhar, L., \& Ramaswamy, S. (2005). "Rieske business: Structure-function of Rieske non-heme oxygenases," Biochemical and Biophysical Research Communications, Celebrating 50 Years of Oxygenases, 338(1), 175-190. DOI: 10.1016/j.bbrc.2005.08.222

Ferraro, D. J., Okerlund, A. L., Mowers, J. C., \& Ramaswamy, S. (2006). "Structural basis for regioselectivity and stereoselectivity of product formation by naphthalene 1,2-dioxygenase," Journal of Bacteriology, 188(19), 6986-6994. DOI: 10.1128/JB.00707-06

Fowler, S. J., Toth, C. R. A., \& Gieg, L. M. (2016). “Community Structure in Methanogenic Enrichments Provides Insight into Syntrophic Interactions in Hydrocarbon-Impacted Environments," Frontiers in Microbiology, 7. DOI: 10.3389/fmicb.2016.00562 
Fox, B. G., Froland, W. A., Dege, J. E., \& Lipscomb, J. D. (1989). "Methane monooxygenase from Methylosinus trichosporium OB3b. Purification and properties of a three-component system with high specific activity from a type II methanotroph," The Journal of Biological Chemistry, 264(17), 10023-10033.

Fritsche, W., \& Hofrichter, M. (2008). "Aerobic Degradation by Microorganisms," in: Biotechnology Set, John Wiley \& Sons, Ltd, 144-167. DOI: 10.1002/9783527620999.ch6m

Fuentes, S., Méndez, V., Aguila, P., \& Seeger, M. (2014). "Bioremediation of petroleum hydrocarbons: catabolic genes, microbial communities, and applications," Applied Microbiology and Biotechnology, 98(11), 47814794. DOI: $10.1007 / \mathrm{s} 00253-014-5684-9$

Fukuhara, Y., Horii, S., Matsuno, T., Matsumiya, Y., Mukai, M., \& Kubo, M. (2013). "Distribution of Hydrocarbon-Degrading Bacteria in the Soil Environment and Their Contribution to Bioremediation," Applied Biochemistry and Biotechnology, 170(2), 329-339. DOI: 10.1007/s12010-013-0170-x

Furukawa, K., Hayase, N., Taira, K., \& Tomizuka, N. (1989). "Molecular relationship of chromosomal genes encoding biphenyl/polychlorinated biphenyl catabolism: some soil bacteria possess a highly conserved bph operon.," Journal of Bacteriology, 171(10), 5467-5472. DOI: 10.1128/jb.171.10.5467-5472.1989

Furukawa, K., \& Miyazaki, T. (1986). "Cloning of a gene cluster encoding biphenyl and chlorobiphenyl degradation in Pseudomonas pseudoalcaligenes.," Journal of Bacteriology, 166(2), 392-398. DOI: 10.1128/jb.166.2.392-398.1986

Furukawa, K., Suenaga, H., \& Goto, M. (2004). "Biphenyl Dioxygenases: Functional Versatilities and Directed Evolution,” Journal of Bacteriology, 186(16), 5189-5196. DOI: 10.1128/JB.186.16.5189-5196.2004

Furusawa, Y., Nagarajan, V., Tanokura, M., Masai, E., Fukuda, M., \& Senda, T. (2004). "Crystal structure of the terminal oxygenase component of biphenyl dioxygenase derived from Rhodococcus sp. strain RHA1," Journal of Molecular Biology, 342(3), 1041-1052. DOI: 10.1016/j.jmb.2004.07.062

Gentry, T., Rensing, C., \& Pepper, I. (2004). "New Approaches for Bioaugmentation as a Remediation Technology," Critical Reviews in Environmental Science and Technology, 34(5), 447-494. DOI: $10.1080 / 10643380490452362$

Gibson, D. T., \& Parales, R. E. (2000). “Aromatic hydrocarbon dioxygenases in environmental biotechnology," Current Opinion in Biotechnology, 11(3), 236-243. DOI: 10.1016/S0958-1669(00)00090-2

Gielnik, A., Pechaud, Y., Huguenot, D., Cébron, A., Riom, J.-M., Guibaud, G., Esposito, G., \& van Hullebusch, E. D. (2019). "Effect of digestate application on microbial respiration and bacterial communities' diversity during bioremediation of weathered petroleum hydrocarbons contaminated soils," Science of The Total Environment, 670, 271-281. DOI: 10.1016/j.scitotenv.2019.03.176

González, C., Lazcano, M., Valdés, J., \& Holmes, D. S. (2016). “Bioinformatic Analyses of Unique (Orphan) Core Genes of the Genus Acidithiobacillus: Functional Inferences and Use As Molecular Probes for Genomic and Metagenomic/Transcriptomic Interrogation," Frontiers in Microbiology, 7. DOI: 10.3389/fmicb.2016.02035

Gonzalez, E., Brereton, N. J. B., Marleau, J., Guidi Nissim, W., Labrecque, M., Pitre, F. E., \& Joly, S. (2015). "Meta-transcriptomics indicates biotic cross-tolerance in willow trees cultivated on petroleum hydrocarbon contaminated soil," BMC Plant Biology, 15, 246. DOI: 10.1186/s12870-015-0636-9

Goyal, A. K., \& Zylstra, G. J. (1996). "Molecular cloning of novel genes for polycyclic aromatic hydrocarbon degradation from Comamonas testosteroni GZ39," Applied and Environmental Microbiology, 62(1), 230236.

Green, J., \& Dalton, H. (1989). "Substrate specificity of soluble methane monooxygenase. Mechanistic implications," The Journal of Biological Chemistry, 264(30), 17698-17703.

Grob, C., Taubert, M., Howat, A. M., Burns, O. J., Chen, Y., Neufeld, J. D., \& Murrell, J. C. (2015). “Generating Enriched Metagenomes from Active Microorganisms with DNA Stable Isotope Probing," in: Hydrocarbon and Lipid Microbiology Protocols, Springer Protocols Handbooks, Springer, Berlin, Heidelberg, 163-180. DOI: 10.1007/8623_2015_81

Grosse, S., Laramee, L., Wendlandt, K. D., McDonald, I. R., Miguez, C. B., \& Kleber, H. P. (1999). "Purification and characterization of the soluble methane monooxygenase of the type II methanotrophic bacterium Methylocystis sp. strain WI 14," Applied and Environmental Microbiology, 65(9), 3929-3935.

Habe, H., Miyakoshi, M., Chung, J., Kasuga, K., Yoshida, T., Nojiri, H., \& Omori, T. (2003). "Phthalate catabolic gene cluster is linked to the angular dioxygenase gene in Terrabacter sp. strain DBF63," Applied Microbiology and Biotechnology, 61(1), 44-54. DOI: 10.1007/s00253-002-1166-6

Habe, H., \& Omori, T. (2003). "Genetics of polycyclic aromatic hydrocarbon metabolism in diverse aerobic bacteria," Bioscience, Biotechnology, and Biochemistry, 67(2), 225-243. DOI: 10.1271/bbb.67.225

Hakemian, A. S., \& Rosenzweig, A. C. (2007). "The Biochemistry of Methane Oxidation," Annual Review of Biochemistry, 76(1), 223-241. DOI: 10.1146/annurev.biochem.76.061505.175355

Hall, K., Miller, C. D., Sorensen, D. L., Anderson, A. J., \& Sims, R. C. (2005). "Development of a catabolically significant genetic probe for polycyclic aromatic hydrocarbon-degrading Mycobacteria in soil," 
Hanson, A. D., Pribat, A., Waller, J. C., \& de Crécy-lagard, V. (2009). “'Unknown' proteins and 'orphan' enzymes: the missing half of the engineering parts list - and how to find it," The Biochemical journal, 425(1), 1-11. DOI: 10.1042/BJ20091328

Hayase, N., Taira, K., \& Furukawa, K. (1990). "Pseudomonas putida KF715 bphABCD operon encoding biphenyl and polychlorinated biphenyl degradation: cloning, analysis, and expression in soil bacteria.," Journal of Bacteriology, 172(2), 1160-1164. DOI: 10.1128/jb.172.2.1160-1164.1990

Head, I. M., Jones, D. M., \& Röling, W. F. M. (2006). "Marine microorganisms make a meal of oil," Nature Reviews Microbiology, 4(3), 173-182. DOI: 10.1038/nrmicro1348

Heitkamp, M. A., and Cerniglia, C. E. (1988). "Mineralization of polycyclic aromatic hydrocarbons by a bacterium isolated from sediment below an oil field.," Applied and Environmental Microbiology, 54(6), $1612-1614$.

Herbst, F.-A., Bahr, A., Duarte, M., Pieper, D. H., Richnow, H.-H., von Bergen, M., Seifert, J., \& Bombach, P. (2013). "Elucidation of in situ polycyclic aromatic hydrocarbon degradation by functional metaproteomics (protein-SIP)," Proteomics, 13(18-19), 2910-2920. DOI: 10.1002/pmic.201200569

Hesham, A. E.-L., Mawad, A. M. M., Mostafa, Y. M., and Shoreit, A. (2014). "Biodegradation Ability and Catabolic Genes of Petroleum-Degrading Sphingomonas koreensis Strain ASU-06 Isolated from Egyptian Oily Soil," BioMed Research International, 2014, e127674. DOI: 10.1155/2014/127674

Hoffmann, T., Horz, H.-P., Kemnitz, D., and Conrad, R. (2002). "Diversity of the Particulate Methane Monooxygenase Gene in Methanotrophic Samples from Different Rice Field Soils in China and the Philippines," Systematic and Applied Microbiology, 25(2), 267-274. DOI: 10.1078/0723-2020-00104

Jakoncic, J., Jouanneau, Y., Meyer, C., \& Stojanoff, V. (2007). "The crystal structure of the ring-hydroxylating dioxygenase from Sphingomonas CHY-1,” The FEBS journal, 274(10), 2470-2481. DOI: 10.1111/j.17424658.2007.05783.x

Jeon, C. O., Park, M., Ro, H.-S., Park, W., \& Madsen, E. L. (2006). "The Naphthalene Catabolic (nag) Genes of Polaromonas naphthalenivorans CJ2: Evolutionary Implications for Two Gene Clusters and Novel Regulatory Control," Applied and Environmental Microbiology, 72(2), 1086-1095. DOI: 10.1128/AEM.72.2.1086-1095.2006

Ji, Y., Mao, G., Wang, Y., \& Bartlam, M. (2013). "Structural insights into diversity and n-alkane biodegradation mechanisms of alkane hydroxylases," Frontiers in Microbiology, 4. DOI: 10.3389/fmicb.2013.00058

Jiao, S., Liu, Z., Lin, Y., Yang, J., Chen, W., \& Wei, G. (2016). "Bacterial communities in oil contaminated soils: Biogeography and co-occurrence patterns," Soil Biology and Biochemistry, 98, 64-73. DOI: 10.1016/j.soilbio.2016.04.005

Jones, M. D., Singleton, D. R., Sun, W., \& Aitken, M. D. (2011). "Multiple DNA Extractions Coupled with Stable-Isotope Probing of Anthracene-Degrading Bacteria in Contaminated Soil," Applied and Environmental Microbiology, 77(9), 2984-2991. DOI: 10.1128/AEM.01942-10

Jouanneau, Y., Martin, F., Krivobok, S., and Willison, J. C. (2011). "Ring-hydroxylating dioxygenases involved in PAH biodegradation: structure, function, biodiversity," in: Microbial bioremediation of non-metals : current research, A.-I. Koukkou, ed., Caister Academic Press, Norfolk, UK., 149-175.

Juck, D., Charles, T., Whyte, L. G., \& Greer, C. W. (2000). "Polyphasic microbial community analysis of petroleum hydrocarbon-contaminated soils from two northern Canadian communities," FEMS Microbiology Ecology, 33(3), 241-249. DOI: 10.1111/j.1574-6941.2000.tb00746.x

Kauppi, B., Lee, K., Carredano, E., Parales, R. E., Gibson, D. T., Eklund, H., \& Ramaswamy, S. (1998). "Structure of an aromatic-ring-hydroxylating dioxygenase - naphthalene 1,2-dioxygenase," Structure, 6(5), 571-586. DOI: 10.1016/S0969-2126(98)00059-8

Keith, L., \& Telliard, W. (1979). "ES\&T Special Report: Priority pollutants: I-a perspective view," Environmental Science \& Technology, 13(4), 416-423. DOI: 10.1021/es60152a601

Khara, P., Roy, M., Chakraborty, J., Ghosal, D., \& Dutta, T. K. (2014). "Functional characterization of diverse ring-hydroxylating oxygenases and induction of complex aromatic catabolic gene clusters in Sphingobium sp. PNB," FEBS open bio, 4, 290-300. DOI: 10.1016/j.fob.2014.03.001

Kim, S.-J., Kweon, O., Jones, R. C., Freeman, J. P., Edmondson, R. D., \& Cerniglia, C. E. (2007). "Complete and Integrated Pyrene Degradation Pathway in Mycobacterium vanbaalenii PYR-1 Based on Systems Biology," Journal of Bacteriology, 189(2), 464-472. DOI: 10.1128/JB.01310-06

Kim, T. J., Lee, E. Y., Kim, Y. J., Cho, K.-S., \& Ryu, H. W. (2003). "Degradation of polyaromatic hydrocarbons by Burkholderia cepacia 2A-12," World Journal of Microbiology and Biotechnology, 19(4), 411-417. DOI: 10.1023/A:1023998719787

Kim, Y.-H., Freeman, J. P., Moody, J. D., Engesser, K.-H., \& Cerniglia, C. E. (2005). "Effects of pH on the degradation of phenanthrene and pyrene by Mycobacterium vanbaalenii PYR-1," Applied Microbiology and Biotechnology, 67(2), 275-285. DOI: 10.1007/s00253-004-1796-y 
Kimura, N., Kato, H., Nishi, A., \& Furukawa, K. (1996). “Analysis of Substrate Range of Biphenyl-catabolic Enzymes,” Bioscience, Biotechnology, and Biochemistry, 60(2), 220-223. DOI: 10.1271/bbb.60.220

Kitmitto, A., Myronova, N., Basu, P., \& Dalton, H. (2005). "Characterization and structural analysis of an active particulate methane monooxygenase trimer from Methylococcus capsulatus (Bath)," Biochemistry, 44(33), 10954-10965. DOI: 10.1021/bi050820u

Kiyohara, H., Nagao, K., Kouno, K., \& Yano, K. (1982). "Phenanthrene-degrading phenotype of Alcaligenes faecalis AFK2," Applied and Environmental Microbiology, 43(2), 458-461.

Kloos, K., Munch, J. C., \& Schloter, M. (2006). "A new method for the detection of alkane-monooxygenase homologous genes (alkB) in soils based on PCR-hybridization," Journal of Microbiological Methods, 66(3), 486-496. DOI: 10.1016/j.mimet.2006.01.014

Kok, M., Oldenhuis, R., van der Linden, M. P., Raatjes, P., Kingma, J., van Lelyveld, P. H., \& Witholt, B. (1989). "The Pseudomonas oleovorans alkane hydroxylase gene. Sequence and expression," The Journal of Biological Chemistry, 264(10), 5435-5441.

Konopka, A. (2009). "What is microbial community ecology?," The ISME Journal, 3(11), 1223-1230. DOI: 10.1038/ismej.2009.88

Kostka, J. E., Prakash, O., Overholt, W. A., Green, S. J., Freyer, G., Canion, A., Delgardio, J., Norton, N., Hazen, T. C., \& Huettel, M. (2011). "Hydrocarbon-Degrading Bacteria and the Bacterial Community Response in Gulf of Mexico Beach Sands Impacted by the Deepwater Horizon Oil Spill," Applied and Environmental Microbiology, 77(22), 7962-7974. DOI: 10.1128/AEM.05402-11

Krivobok, S., Kuony, S., Meyer, C., Louwagie, M., Willison, J. C., \& Jouanneau, Y. (2003). "Identification of Pyrene-Induced Proteins in Mycobacterium sp. Strain 6PY1: Evidence for Two Ring-Hydroxylating Dioxygenases," Journal of Bacteriology, 185(13), 3828-3841. DOI: 10.1128/JB.185.13.3828-3841.2003

Kubota, M., Nodate, M., Yasumoto-Hirose, M., Uchiyama, T., Kagami, O., Shizuri, Y., \& Misawa, N. (2005). "Isolation and functional analysis of cytochrome P450 CYP153A genes from various environments," Bioscience, biotechnology, and biochemistry, 69(12), 2421-2430.

Kweon, O., Kim, S.-J., Baek, S., Chae, J.-C., Adjei, M. D., Baek, D.-H., Kim, Y.-C., \& Cerniglia, C. E. (2008). "A new classification system for bacterial Rieske non-heme iron aromatic ring-hydroxylating oxygenases," BMC Biochemistry, 9, 11. DOI: 10.1186/1471-2091-9-11

Ladino-Orjuela, G., Gomes, E., da Silva, R., Salt, C., \& Parsons, J. R. (2016). "Metabolic Pathways for Degradation of Aromatic Hydrocarbons by Bacteria," in: Reviews of Environmental Contamination and Toxicology Volume 237, Reviews of Environmental Contamination and Toxicology, W. P. de Voogt, ed., Springer International Publishing, Cham, 105-121. DOI: 10.1007/978-3-319-23573-8 5

Laurie, A. D., \& Lloyd-Jones, G. (1999). "The phn genes of Burkholderia sp. strain RP007 constitute a divergent gene cluster for polycyclic aromatic hydrocarbon catabolism," Journal of Bacteriology, 181(2), 531-540.

Leahy, J. G., Batchelor, P. J., \& Morcomb, S. M. (2003). "Evolution of the soluble diiron monooxygenases," FEMS microbiology reviews, 27(4), 449-479.

Leahy, J. G., \& Colwell, R. R. (1990). "Microbial degradation of hydrocarbons in the environment.," Microbiological Reviews, 54(3), 305-315.

Li, L., Liu, X., Yang, W., Xu, F., Wang, W., Feng, L., Bartlam, M., Wang, L., \& Rao, Z. (2008). "Crystal structure of long-chain alkane monooxygenase (LadA) in complex with coenzyme FMN: unveiling the long-chain alkane hydroxylase," Journal of Molecular Biology, 376(2), 453-465. DOI: 10.1016/j.jmb.2007.11.069

Lieberman, R. L., \& Rosenzweig, A. C. (2004). "Biological methane oxidation: regulation, biochemistry, and active site structure of particulate methane monooxygenase," Critical Reviews in Biochemistry and Molecular Biology, 39(3), 147-164. DOI: 10.1080/10409230490475507

Lieberman, R. L., \& Rosenzweig, A. C. (2005). "Crystal structure of a membrane-bound metalloenzyme that catalyses the biological oxidation of methane," Nature, 434(7030), 177-182. DOI: 10.1038/nature03311

Lindstrom, J. E., Barry, R. P., \& Braddock, J. F. (1999). "Long-term effects on microbial communities after a subarctic oil spill," Soil Biology and Biochemistry, 31(12), 1677-1689. DOI: 10.1016/S00380717(99)00081-4

Liu, C., Wang, W., Wu, Y., Zhou, Z., Lai, Q., \& Shao, Z. (2011). "Multiple alkane hydroxylase systems in a marine alkane degrader, Alcanivorax dieselolei B-5," Environmental Microbiology, 13(5), 1168-1178. DOI: $10.1111 /$ j.1462-2920.2010.02416.x

Liu, H., Xu, J., Liang, R., \& Liu, J. (2014). "Characterization of the Medium- and Long-Chain n-Alkanes Degrading Pseudomonas aeruginosa Strain SJTD-1 and Its Alkane Hydroxylase Genes," PLOS ONE, 9(8), e105506. DOI: 10.1371/journal.pone.0105506

Liu, Q., Tang, J., Bai, Z., Hecker, M., \& Giesy, J. P. (2015). “Distribution of petroleum degrading genes and factor analysis of petroleum contaminated soil from the Dagang Oilfield, China," Scientific Reports, 5. DOI: $10.1038 /$ srep 11068 
Lloyd-Jones, G., Laurie, A. D., Hunter, D. W. F., \& Fraser, R. (1999). "Analysis of catabolic genes for naphthalene and phenanthrene degradation in contaminated New Zealand soils," FEMS Microbiology Ecology, 29(1), 69-79. DOI: 10.1016/S0168-6496(98)00131-7

Lu, X.-Y., Zhang, T., \& Fang, H. H.-P. (2011). "Bacteria-mediated PAH degradation in soil and sediment," Applied Microbiology and Biotechnology, 89(5), 1357-1371. DOI: 10.1007/s00253-010-3072-7

Lueders, T. (2015). "DNA- and RNA-Based Stable Isotope Probing of Hydrocarbon Degraders," in: Hydrocarbon and Lipid Microbiology Protocols, Springer Protocols Handbooks, Springer, Berlin, Heidelberg, 181-197. DOI: 10.1007/8623_2015_74

Lundstedt, S., Haglund, P., \& Öberg, L. (2003). "Degradation and formation of polycyclic aromatic compounds during bioslurry treatment of an aged gasworks soil," Environmental Toxicology and Chemistry, 22(7), 1413-1420. DOI: 10.1002/etc.5620220701

Ma, Z. (Sam), Zhang, C., Zhang, Q., Li, J., Li, L., Qi, L., \& Yang, X. (2016). “A Brief Review on the Ecological Network Analysis with Applications in the Emerging Medical Ecology," in: Hydrocarbon and Lipid Microbiology Protocols: Statistics, Data Analysis, Bioinformatics and Modelling, Springer Protocols Handbooks, T. J. McGenity, K. N. Timmis, \& B. Nogales Fernández, eds., Springer Berlin Heidelberg, Berlin, Heidelberg, 7-39. DOI: 10.1007/8623 2016204

MacNaughton, S. J., Stephen, J. R., Venosa, A. D., Davis, G. A., Chang, Y. J., \& White, D. C. (1999). "Microbial population changes during bioremediation of an experimental oil spill," Applied and Environmental Microbiology, 65(8), 3566-3574.

Maier, T., Förster, H. H., Asperger, O., \& Hahn, U. (2001). "Molecular characterization of the 56-kDa CYP153 from Acinetobacter sp. EB104,” Biochemical and Biophysical Research Communications, 286(3), 652-658. DOI: $10.1006 /$ bbrc. 2001.5449

Marcos, M. S., Lozada, M., \& Dionisi, H. M. (2009). "Aromatic hydrocarbon degradation genes from chronically polluted Subantarctic marine sediments," Letters in Applied Microbiology, 49(5), 602-608. DOI: 10.1111/j.1472-765X.2009.02711.x

Martin, F., Malagnoux, L., Violet, F., Jakoncic, J., and Jouanneau, Y. (2013). "Diversity and catalytic potential of PAH-specific ring-hydroxylating dioxygenases from a hydrocarbon-contaminated soil," Applied Microbiology and Biotechnology, 97(11), 5125-5135. DOI: 10.1007/s00253-012-4335-2

Massart, L., \& Vercauteren, R. (1959). "Oxygenases and Hydroxylases,” Annual Review of Biochemistry, 28(1), 527-544. DOI: 10.1146/annurev.bi.28.070159.002523

McDonald, I. R., Miguez, C. B., Rogge, G., Bourque, D., Wendlandt, K. D., Groleau, D., and Murrell, J. C. (2006). "Diversity of soluble methane monooxygenase-containing methanotrophs isolated from polluted environments," FEMS Microbiology Letters, 255(2), 225-232. DOI: 10.1111/j.1574-6968.2005.00090.x

de Menezes, A., Clipson, N., \& Doyle, E. (2012). "Comparative metatranscriptomics reveals widespread community responses during phenanthrene degradation in soil," Environmental Microbiology, 14(9), 25772588. DOI: $10.1111 / \mathrm{j} .1462-2920.2012 .02781 . \mathrm{x}$

Merkx, M., Kopp, D. A., Sazinsky, M. H., Blazyk, J. L., Müller, J., \& Lippard, S. J. (2001). "Dioxygen Activation and Methane Hydroxylation by Soluble Methane Monooxygenase: A Tale of Two Irons and Three Proteins," Angewandte Chemie International Edition, 40(15), 2782-2807. DOI: 10.1002/15213773(20010803)40:15<2782::AID-ANIE2782>3.0.CO;2-P

Mesarch, M. B., Nakatsu, C. H., \& Nies, L. (2000). "Development of Catechol 2,3-Dioxygenase-Specific Primers for Monitoring Bioremediation by Competitive Quantitative PCR," Applied and Environmental Microbiology, 66(2), 678-683.

Mondello, F. J. (1989). "Cloning and expression in Escherichia coli of Pseudomonas strain LB400 genes encoding polychlorinated biphenyl degradation.," Journal of Bacteriology, 171(3), 1725-1732.

Morelli, I. S., Saparrat, M. C. N., Panno, M. T. D., Coppotelli, B. M., \& Arrambari, A. (2013). "Bioremediation of PAH-Contaminated Soil by Fungi," in: Fungi as Bioremediators, Soil Biology, E. M. Goltapeh, Y. R. Danesh, \& A. Varma, eds., Springer Berlin Heidelberg, 159-179. DOI: 10.1007/978-3-642-33811-3_7

Nakajima, T., Uchiyama, H., Yagi, O., \& Nakahara, T. (1992). "Purification and Properties of a Soluble Methane Monooxygenase from Methylocystis sp. M," Bioscience, Biotechnology, and Biochemistry, 56(5), 736-740. DOI: 10.1271/bbb.56.736

Nam, J. W., Nojiri, H., Yoshida, T., Habe, H., Yamane, H., \& Omori, T. (2001). "New classification system for oxygenase components involved in ring-hydroxylating oxygenations," Bioscience, Biotechnology, and Biochemistry, 65(2), 254-263. DOI: 10.1271/bbb.65.254

Notomista, E., Lahm, A., Donato, A. D., \& Tramontano, A. (2003). "Evolution of Bacterial and Archaeal Multicomponent Monooxygenases," Journal of Molecular Evolution, 56(4), 435-445. DOI: 10.1007/s00239-002-2414-1

Obayori, O. S., \& Salam, L. B. (2010). "Degradation of polycyclic aromatic hydrocarbons: Role of plasmids," Scientific Research and Essays, 5(25), 4093-4106. 
OECD "Glossary of Statistical Terms - $\quad$ Biodegradation Definition." (n.d.). $<$ https://stats.oecd.org/glossary/detail.asp?ID=203> (Nov. 15, 2016).

Ogino, A., Koshikawa, H., Nakahara, T., \& Uchiyama, H. (2001). "Succession of microbial communities during a biostimulation process as evaluated by DGGE and clone library analyses," Journal of Applied Microbiology, 91(4), 625-635. DOI: 10.1046/j.1365-2672.2001.01424.x

Pandey, A., \& Mann, M. (2000). "Proteomics to study genes and genomes," Nature, 405, 837-846. DOI: $10.1038 / 35015709$

Paniagua-Michel, J., \& Fathepure, B. Z. (2018). "Microbial Consortia and Biodegradation of Petroleum Hydrocarbons in Marine Environments," in: Microbial Action on Hydrocarbons, V. Kumar, M. Kumar, and R. Prasad, eds., Springer Singapore, Singapore, 1-20. DOI: 10.1007/978-981-13-1840-5_1

Parales, R. E., Emig, M. D., Lynch, N. A., \& Gibson, D. T. (1998). "Substrate Specificities of Hybrid Naphthalene and 2,4-Dinitrotoluene Dioxygenase Enzyme Systems," Journal of Bacteriology, 180(9), 2337-2344.

Patel, V., Sharma, A., Lal, R., Al-Dhabi, N. A., \& Madamwar, D. (2016). "Response and resilience of soil microbial communities inhabiting in edible oil stress/contamination from industrial estates," $B M C$ Microbiology, 16, 50. DOI: 10.1186/s12866-016-0669-8

Peng, J.-J., Cai, C., Qiao, M., Li, H., \& Zhu, Y.-G. (2010). "Dynamic changes in functional gene copy numbers and microbial communities during degradation of pyrene in soils," Environmental Pollution (Barking, Essex: 1987), 158(9), 2872-2879. DOI: 10.1016/j.envpol.2010.06.020

Peng, R.-H., Xiong, A.-S., Xue, Y., Fu, X.-Y., Gao, F., Zhao, W., Tian, Y.-S., \& Yao, Q.-H. (2008). "Microbial biodegradation of polyaromatic hydrocarbons," FEMS Microbiology Reviews, 32(6), 927-955. DOI: 10.1111/j.1574-6976.2008.00127.x

Pérez-de-Mora, A., Engel, M., \& Schloter, M. (2011). "Abundance and Diversity of n-Alkane-Degrading Bacteria in a Forest Soil Co-Contaminated with Hydrocarbons and Metals: A Molecular Study on alkB Homologous Genes," Microbial Ecology, 62(4), 959-972. DOI: 10.1007/s00248-011-9858-z

Pérez-Pantoja, D., \& Tamames, J. (2015). "Prokaryotic Metatranscriptomics," in: Hydrocarbon and Lipid Microbiology Protocols, Springer Protocols Handbooks, Springer, Berlin, Heidelberg, 69-98. DOI: $10.1007 / 86232015 \quad 146$

Pieja, A. J., Sundstrom, E. R., \& Criddle, C. S. (2011). "Poly-3-hydroxybutyrate metabolism in the type II methanotroph Methylocystis parvus OBBP," Applied and Environmental Microbiology, 77(17), 6012-6019. DOI: 10.1128/AEM.00509-11

Pinholt, Y., Struwe, S., \& Kjøller, A. (1979). "Microbial Changes during Oil Decomposition in Soil," Holarctic Ecology, 2(3), 195-200.

Popp, N., Schlömann, M., \& Mau, M. (2006). "Bacterial diversity in the active stage of a bioremediation system for mineral oil hydrocarbon-contaminated soils," Microbiology, 152(11), 3291-3304. DOI: 10.1099/mic.0.29054-0

R, M. I., \& J.Colin, M. (1997). "The particulate methane monooxygenase gene pmoA and its use as a functional gene probe for methanotrophs," FEMS Microbiology Letters, 156(2), 205-210. DOI: 10.1111/j.15746968.1997.tb12728.x

Ratajczak, A., Geißdörfer, W., \& Hillen, W. (1998). “Alkane Hydroxylase from Acinetobacter sp. Strain ADP1 Is Encoded by alkM and Belongs to a New Family of Bacterial Integral-Membrane Hydrocarbon Hydroxylases," Applied and Environmental Microbiology, 64(4), 1175-1179.

Reed, J. J. (2011). "Special Publication 922 Polycyclic Aromatic Hydrocarbon Structure Index," NIST, $<$ https://www.nist.gov/mml/csd/special-publication-922-polycyclic-aromatic-hydrocarbon-structure-index $>$ (Jul. 2, 2018).

Reid, T., Chaganti, S. R., Droppo, I. G., \& Weisener, C. G. (2018). "Novel insights into freshwater hydrocarbonrich sediments using metatranscriptomics: Opening the black box," Water Research, 136, 1-11. DOI: 10.1016/j.watres.2018.02.039

Ren, G., Ren, W., Teng, Y., \& Li, Z. (2015). "Evident bacterial community changes but only slight degradation when polluted with pyrene in a red soil," Frontiers in Microbiology, 6. DOI: 10.3389/fmicb.2015.00022

Roey, A., \& Ralf, C. (2009). "In situ measurement of methane fluxes and analysis of transcribed particulate methane monooxygenase in desert soils," Environmental Microbiology, 11(10), 2598-2610. DOI: $10.1111 /$ j.1462-2920.2009.01984.x

Rojo, F. (2009). "Degradation of alkanes by bacteria," Environmental Microbiology, 11(10), 2477-2490. DOI: 10.1111/j.1462-2920.2009.01948.x

Röling, W. F. M., Bodegom, V., \& M, P. (2014a). “Toward quantitative understanding on microbial community structure and functioning: a modeling-centered approach using degradation of marine oil spills as example," Frontiers in Microbiology, 5. DOI: 10.3389/fmicb.2014.00125

Röling, W. F. M., de Brito Couto, I. R., Swannell, R. P. J., \& Head, I. M. (2004). "Response of Archaeal 
communities in beach sediments to spilled oil and bioremediation," Applied and Environmental Microbiology, 70(5), 2614-2620.

Röling, W. F. M., Fillinger, L., \& Rocha, U. N. da. (2014b). "Analysis of the Regulation of the Rate of Hydrocarbon and Nutrient Flow Through Microbial Communities," in: Hydrocarbon and Lipid Microbiology Protocols, Springer Protocols Handbooks, Springer, Berlin, Heidelberg, 233-246. DOI: 10.1007/8623_2014_15

Röling, W. F. M., Milner, M. G., Jones, D. M., Fratepietro, F., Swannell, R. P. J., Daniel, F., \& Head, I. M. (2004). "Bacterial Community Dynamics and Hydrocarbon Degradation during a Field-Scale Evaluation of Bioremediation on a Mudflat Beach Contaminated with Buried Oil," Applied and Environmental Microbiology, 70(5), 2603-2613. DOI: 10.1128/AEM.70.5.2603-2613.2004

Röling, W. F. M., Milner, M. G., Jones, D. M., Lee, K., Daniel, F., Swannell, R. J. P., \& Head, I. M. (2002). "Robust Hydrocarbon Degradation and Dynamics of Bacterial Communities during Nutrient-Enhanced Oil Spill Bioremediation," Applied and Environmental Microbiology, 68(11), 5537-5548. DOI: 10.1128/AEM.68.11.5537-5548.2002

Romine, M. F., Stillwell, L. C., Wong, K.-K., Thurston, S. J., Sisk, E. C., Sensen, C., Gaasterland, T., Fredrickson, J. K., \& Saffer, J. D. (1999). "Complete Sequence of a 184-Kilobase Catabolic Plasmid from Sphingomonas aromaticivorans F199,” Journal of Bacteriology, 181(5), 1585-1602.

Rosenzweig, A. C., Frederick, C. A., Lippard, S. J., \& Nordlund, P. (1993). "Crystal structure of a bacterial nonhaem iron hydroxylase that catalyses the biological oxidation of methane," Nature, 366(6455), 537-543. DOI: $10.1038 / 366537 \mathrm{a} 0$

Roy, A., Dutta, A., Pal, S., Gupta, A., Sarkar, J., Chatterjee, A., Saha, A., Sarkar, P., Sar, P., \& Kazy, S. K. (2018). "Biostimulation and bioaugmentation of native microbial community accelerated bioremediation of oil refinery sludge," Bioresource Technology, 253, 22-32. DOI: 10.1016/j.biortech.2018.01.004

Saito, A., Iwabuchi, T., \& Harayama, S. (1999). "Characterization of genes for enzymes involved in the phenanthrene degradation in Nocardioides sp. KP7," Chemosphere, Degradation Processes in the Environment, 38(6), 1331-1337. DOI: 10.1016/S0045-6535(98)00534-7

Schneider, J., Grosser, R., Jayasimhulu, K., Xue, W., \& Warshawsky, D. (1996). "Degradation of pyrene, benz[a]anthracene, and benzo[a]pyrene by Mycobacterium sp. strain RJGII-135, isolated from a former coal gasification site.," Applied and Environmental Microbiology, 62(1), 13-19.

Seeger, M., \& Pieper, D. H. (2010). “Genetics of Biphenyl Biodegradation and Co-Metabolism of PCBs," in: Handbook of Hydrocarbon and Lipid Microbiology, Springer, Berlin, Heidelberg, 1179-1199. DOI: 10.1007/978-3-540-77587-4 82

Sekine, M., Tanikawa, S., Omata, S., Saito, M., Fujisawa, T., Tsukatani, N., Tajima, T., Sekigawa, T., Kosugi, H., Matsuo, Y., Nishiko, R., Imamura, K., Ito, M., Narita, H., Tago, S., Fujita, N., \& Harayama, S. (2006). "Sequence analysis of three plasmids harboured in Rhodococcus erythropolis strain PR4," Environmental Microbiology, 8(2), 334-346. DOI: 10.1111/j.1462-2920.2005.00899.x

Seo, J.-S., Keum, Y.-S., Hu, Y., Lee, S.-E., \& Li, Q. X. (2006). "Phenanthrene degradation in Arthrobacter sp. P1-1: initial 1,2-, 3,4- and 9,10-dioxygenation, and meta- and ortho-cleavages of naphthalene-1,2-diol after its formation from naphthalene-1,2-dicarboxylic acid and hydroxyl naphthoic acids," Chemosphere, 65(11), 2388-2394. DOI: 10.1016/j.chemosphere.2006.04.067

Seo, J.-S., Keum, Y.-S., \& Li, Q. X. (2009). "Bacterial Degradation of Aromatic Compounds," International Journal of Environmental Research and Public Health, 6(1), 278-309. DOI: 10.3390/ijerph6010278

Shahsavari, E., Aburto-Medina, A., Taha, M., \& Ball, A. S. (2016). "A quantitative PCR approach for quantification of functional genes involved in the degradation of polycyclic aromatic hydrocarbons in contaminated soils," MethodsX, 3, 205-211. DOI: 10.1016/j.mex.2016.02.005

Sharpton, T. J. (2014). "An introduction to the analysis of shotgun metagenomic data," Frontiers in Plant Science, 5. DOI: 10.3389/fpls.2014.00209

Siggins, A., Gunnigle, E., \& Abram, F. (2012). "Exploring mixed microbial community functioning: recent advances in metaproteomics," FEMS Microbiology Ecology, 80(2), 265-280. DOI: 10.1111/j.15746941.2011.01284.x

Simon, M. J., Osslund, T. D., Saunders, R., Ensley, B. D., Suggs, S., Harcourt, A., Suen, W. C., Cruden, D. L., Gibson, D. T., \& Zylstra, G. J. (1993). "Sequences of genes encoding naphthalene dioxygenase in Pseudomonas putida strains G7 and NCIB 9816-4," Gene, 127(1), 31-37.

Singleton, D. R., Ramirez, L. G., \& Aitken, M. D. (2009). "Characterization of a Polycyclic Aromatic Hydrocarbon Degradation Gene Cluster in a Phenanthrene-Degrading Acidovorax Strain," Applied and Environmental Microbiology, 75(9), 2613-2620. DOI: 10.1128/AEM.01955-08

Smith, C. B., Tolar, B. B., Hollibaugh, J. T., \& King, G. M. (2013). “Alkane hydroxylase gene (alkB) phylotype composition and diversity in northern Gulf of Mexico bacterioplankton," Frontiers in Microbiology, 4. DOI: 10.3389/fmicb.2013.00370 
Smith, S. M., Rawat, S., Telser, J., Hoffman, B. M., Stemmler, T. L., \& Rosenzweig, A. C. (2011). "Crystal Structure and Characterization of Particulate Methane Monooxygenase from Methylocystis species Strain M," Biochemistry, 50(47), 10231-10240. DOI: 10.1021/bi200801z

Smits, T. H. M., Balada, S. B., Witholt, B., \& Beilen, J. B. van. (2002). "Functional Analysis of Alkane Hydroxylases from Gram-Negative and Gram-Positive Bacteria," Journal of Bacteriology, 184(6), 17331742. DOI: $10.1128 / J B .184 .6 .1733-1742.2002$

Sohn, J. H., Kwon, K. K., Kang, J.-H., Jung, H.-B., \& Kim, S.-J. (2004). "Novosphingobium pentaromativorans sp. nov., a high-molecular-mass polycyclic aromatic hydrocarbon-degrading bacterium isolated from estuarine sediment," International Journal of Systematic and Evolutionary Microbiology, 54(5), 1483-1487. DOI: 10.1099/ijs.0.02945-0

Staijen, I. E., van Beilen, J. B., \& Witholt, B. (2000). "Expression, stability and performance of the threecomponent alkane mono-oxygenase of Pseudomonas oleovorans in Escherichia coli: Engineering of E. coli for alkane oxidation," European Journal of Biochemistry, 267(7), 1957-1965. DOI: 10.1046/j.14321327.2000.01196.x

Succurro, A., \& Ebenhöh, O. (2018). "Review and perspective on mathematical modeling of microbial ecosystems," Biochemical Society Transactions, 46(2), 403-412. DOI: 10.1042/BST20170265

Takeda, Y., Takase, K., Yamato, I., \& Abe, K. (1998). "Sequencing and Characterization of the xyl Operon of a Gram-Positive Bacterium, Tetragenococcus halophila," Applied and Environmental Microbiology, 64(7), 2513-2519.

Tani, A., Ishige, T., Sakai, Y., \& Kato, N. (2001). "Gene Structures and Regulation of the Alkane Hydroxylase Complex in Acinetobacter sp. Strain M-1," Journal of Bacteriology, 183(5), 1819-1823. DOI: 10.1128/JB.183.5.1819-1823.2001

Thakur, M. (2014). "Mycoremediation - a potential tool to control soil pollution.," Asian Journal of Environmental Science, 9(1), 24-31.

Throne-Holst, M., Wentzel, A., Ellingsen, T. E., Kotlar, H.-K., \& Zotchev, S. B. (2007). "Identification of Novel Genes Involved in Long-Chain n-Alkane Degradation by Acinetobacter sp. Strain DSM 17874," Applied and Environmental Microbiology, 73(10), 3327-3332. DOI: 10.1128/AEM.00064-07

Torres Pazmiño, D. E., Winkler, M., Glieder, A., \& Fraaije, M. W. (2010). "Monooxygenases as biocatalysts: Classification, mechanistic aspects and biotechnological applications," Journal of Biotechnology, 146(1-2), 9-24. DOI: 10.1016/j.jbiotec.2010.01.021

Tuomi, P. M., Salminen, J. M., \& Jørgensen, K. S. (2004). "The abundance of nahAc genes correlates with the 14C-naphthalene mineralization potential in petroleum hydrocarbon-contaminated oxic soil layers," FEMS microbiology ecology, 51(1), 99-107. DOI: 10.1016/j.femsec.2004.07.011

Varjani, S. J. (2017). "Microbial degradation of petroleum hydrocarbons," Bioresource Technology, 223, $277-$ 286. DOI: 10.1016/j.biortech.2016.10.037

Vila, J., Tauler, M., \& Grifoll, M. (2015). "Bacterial PAH degradation in marine and terrestrial habitats," Current Opinion in Biotechnology, Environmental biotechnology • Energy biotechnology, 33, 95-102. DOI: 10.1016/j.copbio.2015.01.006

Vitorino, L. C., \& Bessa, L. A. (2017). "Technological Microbiology: Development and Applications," Frontiers in Microbiology, 8. DOI: 10.3389/fmicb.2017.00827

Wade, M. J., Harmand, J., Benyahia, B., Bouchez, T., Chaillou, S., Cloez, B., Godon, J.-J., Moussa Boudjemaa, B., Rapaport, A., Sari, T., Arditi, R., \& Lobry, C. (2016). "Perspectives in mathematical modelling for microbial ecology," Ecological Modelling, 321, 64-74. DOI: 10.1016/j.ecolmodel.2015.11.002

Walter, U., Beyer, M., Klein, J., \& Rehm, H.-J. (1991). "Degradation of pyrene byRhodococcus sp. UW1," Applied Microbiology and Biotechnology, 34(5), 671-676. DOI: 10.1007/BF00167921

Wang, R. F., Wennerstrom, D., Cao, W. W., Khan, A. A., \& Cerniglia, C. E. (2000). "Cloning, Expression, and Characterization of the katGGene, Encoding Catalase-Peroxidase, from the Polycyclic Aromatic Hydrocarbon-Degrading Bacterium Mycobacterium sp. Strain PYR-1," Applied and Environmental Microbiology, 66(10), 4300-4304. DOI: 10.1128/AEM.66.10.4300-4304.2000

Wang, W., \& Shao, Z. (2012). "Diversity of flavin-binding monooxygenase genes (almA) in marine bacteria capable of degradation long-chain alkanes," FEMS microbiology ecology, 80(3), 523-533. DOI: 10.1111/j.1574-6941.2012.01322.x

Wentzel, A., Ellingsen, T. E., Kotlar, H., Zotchev, S. B., and Throne-holst, M. (2007). "Bacterial metabolism of long-chain n-alkanes," Applied Microbiology and Biotechnology, 76(6), 1209-21. DOI: http://dx.doi.org.vu-nl.idm.oclc.org/10.1007/s00253-007-1119-1

Whitby, Corinne, \& Skovhus, Torben Lund (Eds.). (n.d.). Applied Microbiology and Molecular Biology in Oilfield.

Whyte, L. G., Schultz, A., van Beilen, J. B., Luz, A. P., Pellizari, V., Labbé, D., \& Greer, C. W. (2002). "Prevalence of alkane monooxygenase genes in Arctic and Antarctic hydrocarbon-contaminated and 
pristine soils1Issued as NRC 44660 (National Council of Canada).," FEMS Microbiology Ecology, 41(2), 141-150. DOI: 10.1111/j.1574-6941.2002.tb00975.x

Wick, L. Y., Pasche, N., Bernasconi, S. M., Pelz, O., \& Harms, H. (2003). "Characterization of MultipleSubstrate Utilization by Anthracene-Degrading Mycobacterium frederiksbergense LB501T," Applied and Environmental Microbiology, 69(10), 6133-6142. DOI: 10.1128/AEM.69.10.6133-6142.2003

Widada, J., Nojiri, H., Kasuga, K., Yoshida, T., Habe, H., \& Omori, T. (2002). "Molecular detection and diversity of polycyclic aromatic hydrocarbon-degrading bacteria isolated from geographically diverse sites," Applied Microbiology and Biotechnology, 58(2), 202-209. DOI: 10.1007/s00253-001-0880-9

Williams, M. A., Taylor, E. B., \& Mula, H. P. (2010). "Metaproteomic characterization of a soil microbial community following carbon amendment," Soil Biology and Biochemistry, 42(7), 1148-1156. DOI: 10.1016/j.soilbio.2010.03.021

Wilson, S. C., \& Jones, K. C. (1993). "Bioremediation of soil contaminated with polynuclear aromatic hydrocarbons (PAHs): A review," Environmental Pollution, 81(3), 229-249. DOI: 10.1016/02697491(93)90206-4

Xiao, Y., Angulo, M. T., Friedman, J., Waldor, M. K., Weiss, S. T., \& Liu, Y.-Y. (2017). "Mapping the ecological networks of microbial communities," Nature Communications, 8(1), 2042. DOI: 10.1038/s41467-017-02090-2

Yang, S., Wen, X., Shi, Y., Liebner, S., Jin, H., \& Perfumo, A. (2016). "Hydrocarbon degraders establish at the costs of microbial richness, abundance and keystone taxa after crude oil contamination in permafrost environments," Scientific Reports, 6, 37473. DOI: 10.1038/srep37473

Yu, C. L., Liu, W., Ferraro, D. J., Brown, E. N., Parales, J. V., Ramaswamy, S., Zylstra, G. J., Gibson, D. T., \& Parales, R. E. (2007). "Purification, characterization, and crystallization of the components of a biphenyl dioxygenase system from Sphingobium yanoikuyae B1," Journal of Industrial Microbiology \& Biotechnology; Fairfax, 34(4), 311-24. DOI: http://dx.doi.org/10.1007/s10295-006-0199-8

Zhou, N.-Y., Fuenmayor, S. L., \& Williams, P. A. (2001). "nag Genes ofRalstonia (Formerly Pseudomonas) sp. Strain U2 Encoding Enzymes for Gentisate Catabolism," Journal of Bacteriology, 183(2), 700-708. DOI: 10.1128/JB.183.2.700-708.2001

Ziegler, D. M. (2002). “An overview of the mechanism, substrate specificities, and structure of FMOs," Drug Metabolism Reviews, 34(3), 503-511. DOI: 10.1081/DMR-120005650

Zylstra, G. J., \& Gibson, D. T. (1989). "Toluene degradation by Pseudomonas putida F1. Nucleotide sequence of the todC1C2BADE genes and their expression in Escherichia coli.," Journal of Biological Chemistry, 264(25), 14940-14946. 


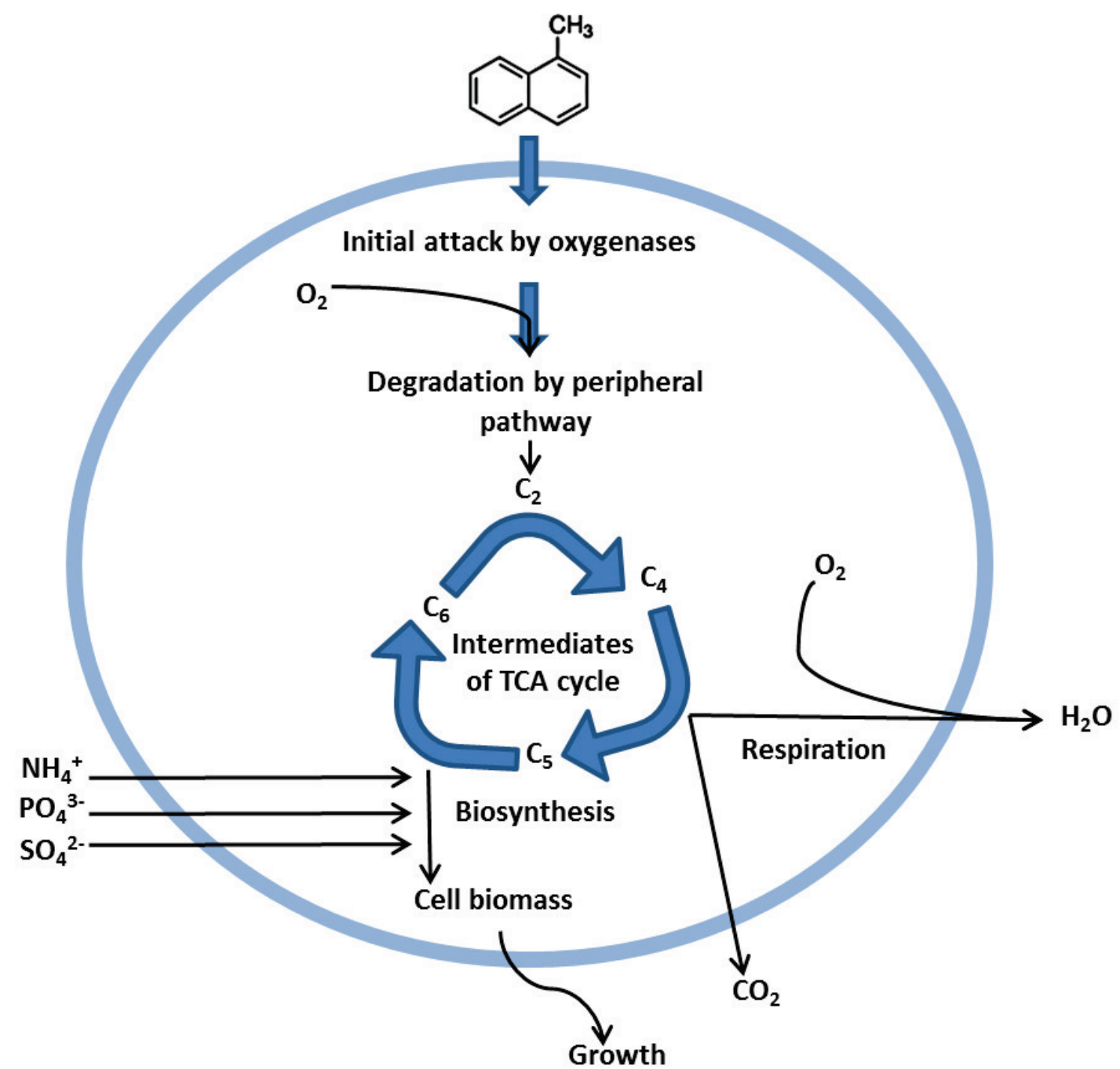

Figure 1. Principle of aerobic degradation of hydrocarbons for growth associated processes. Adapted from Fritsche \& Hofrichter (2000)

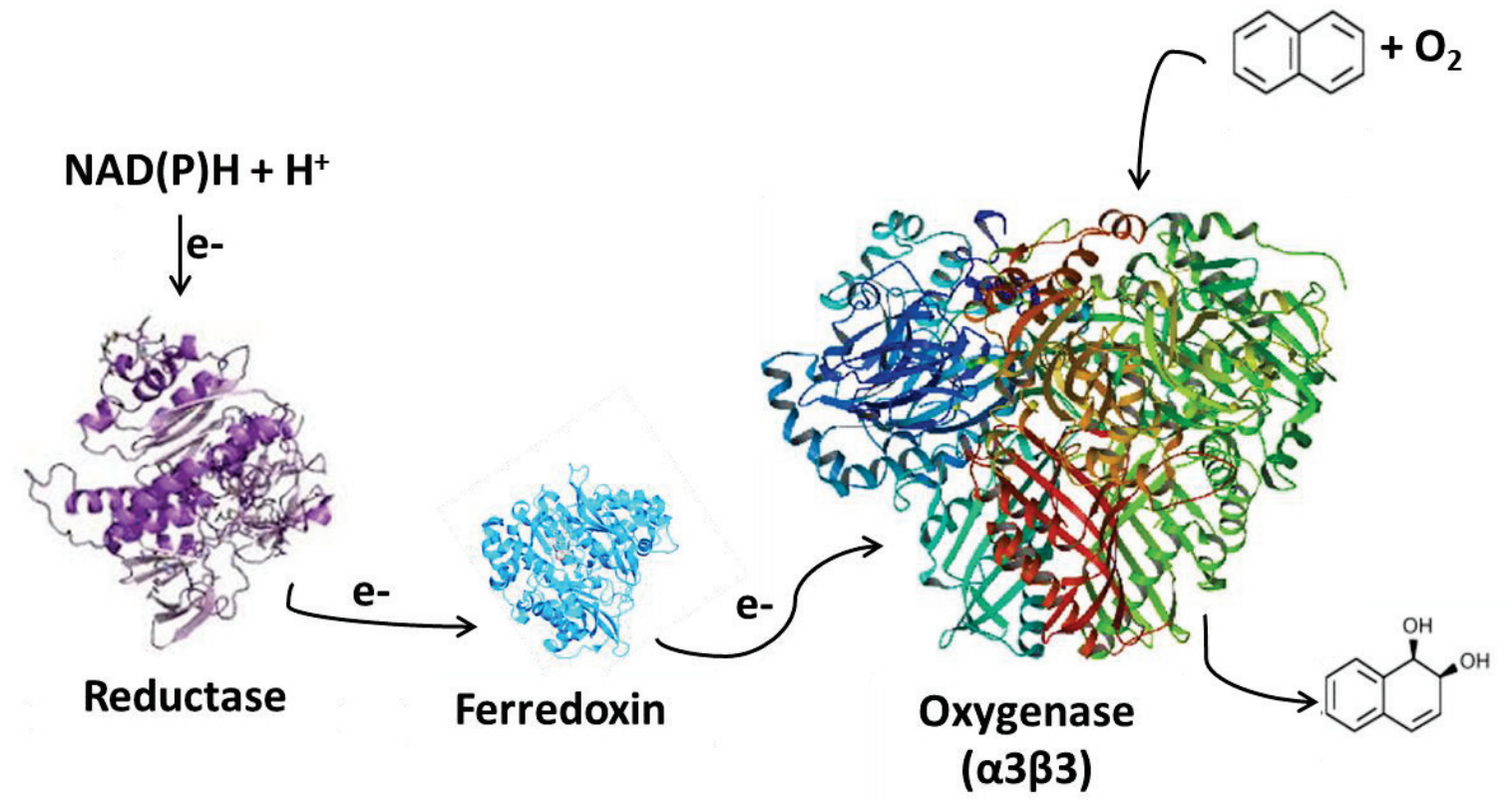

Figure 2. Composition of and electron flow within a Rieske non-heme iron oxygenases. Adapted from Chakraborty et al. (2014). 


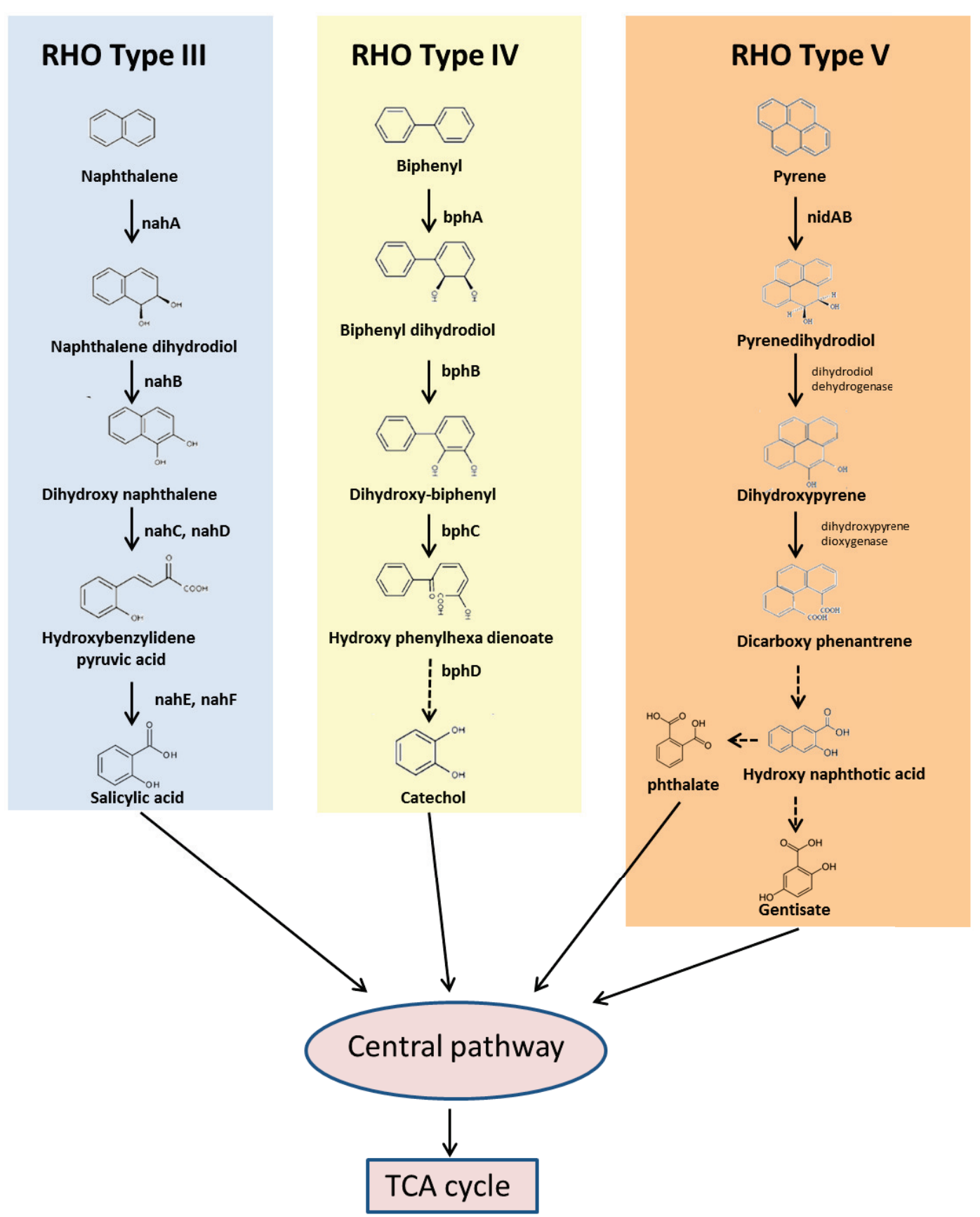

Figure 3. Pathways attributed to each sub family of ring hydroxylating oxygenase (RHO) for aromatic hydrocarbon degradation. i) RHO type III genes are part of operon nahABFCED that encodes six enzymes for the conversion of naphthalene into salicylic acid in Pseudomonas putida G. ii) RHO type IV genes are part of the bphABCD operon that encodes seven enzymes to transform biphenyl into catechol in Burkholderia xenovorans LB400. iii) RHO type V genes are present in several complex gene clusters that encode enzymes to break down pyrene into phthalate or gentisate in Mycobacterium PYR-1. 


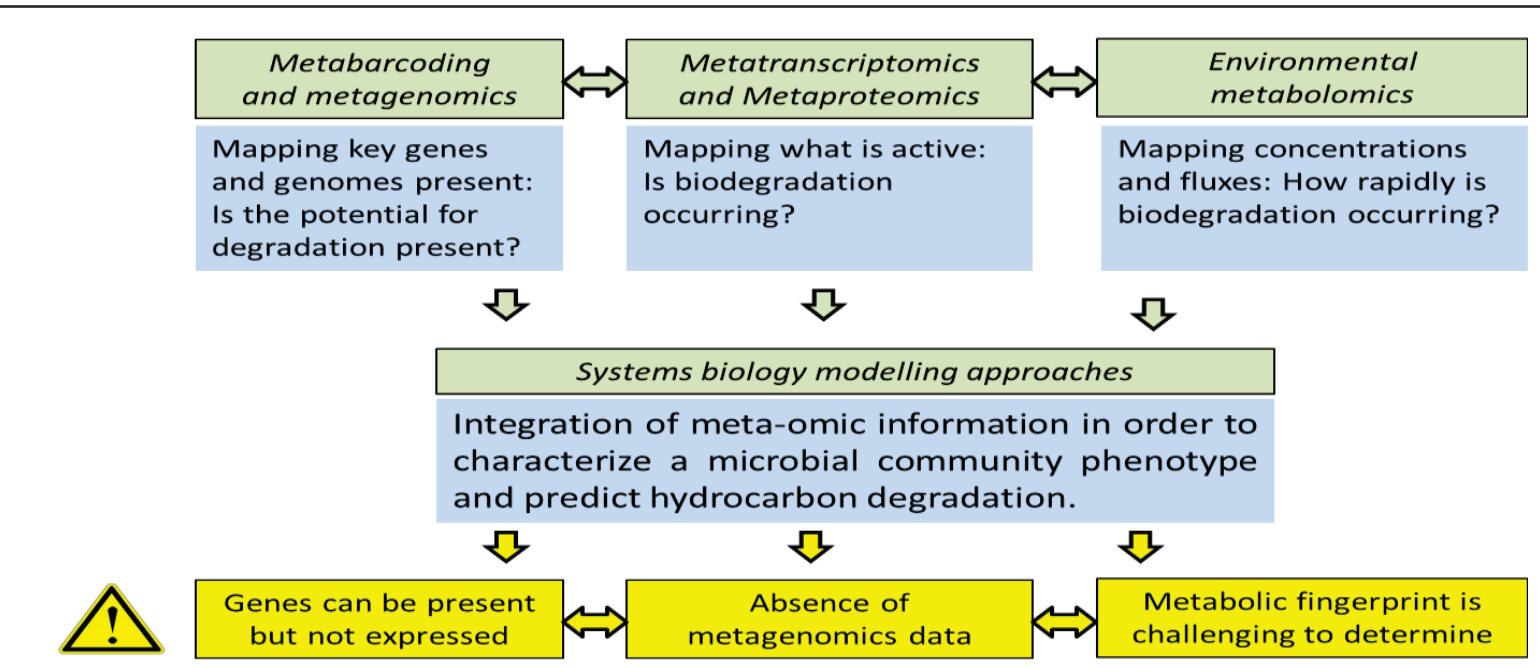

Figure 4. Flow chart of recent technologies for bioremediation of petroleum hydrocarbons and principal limitations.

Table 1. Alkane hydroxylases in microbial communities

\begin{tabular}{|c|c|c|c|}
\hline Enzyme system & $\begin{array}{l}\text { Composition and } \\
\text { cofactors }\end{array}$ & $\begin{array}{l}\text { Substrate } \\
\text { range }\end{array}$ & Reference \\
\hline $\begin{array}{l}\text { Particulate alkane } \\
\text { hydroxylases } \\
\text { (pAH/AlkB) }\end{array}$ & $\begin{array}{l}\text { Membrane hydroxylase: } \\
\text { binuclear iron } \\
\text { Rubredoxin: iron } \\
\text { Rubredoxin } \\
\text { reductase: FAD, NADH }\end{array}$ & $\mathrm{C}_{3}$ to $\mathrm{C}_{16}$ & $\begin{array}{l}\text { Pseudomonas putida } \\
\text { (Baptist et al. } 1963 \text { ) } \\
\text { Acinetobacter } \\
\text { (Ratajczak et al. } 1998 \text { ) } \\
\text { Alcanivorax, Burkholderia, Mycobacterium, } \\
\text { Pseudomonas and Rhodococcus } \\
\text { (Beilen et al. 2003). }\end{array}$ \\
\hline $\begin{array}{l}\text { Cytochrome P450 } \\
\text { (CYP) }\end{array}$ & $\begin{array}{l}\text { P450 oxygenase: } \mathrm{P} 450 \\
\text { heme } \\
\text { ferredoxin: } \\
\text { iron-sulfur } \\
\text { ferredoxin reductase: } \\
\text { FAD, NADH }\end{array}$ & $\mathrm{C}_{5}$ to $\mathrm{C}_{16}$ & $\begin{array}{l}\text { Acinetobacter sp. } \\
\text { (Maier et al. 2001) } \\
\text { Mycobacterium } \\
\text { (van Beilen } \text { et al. 2005) } \\
\text { Rhodococcus } \\
\text { (Sekine et al. 2006) }\end{array}$ \\
\hline $\begin{array}{l}\text { Flavin-dependent } \\
\text { monooxygenases } \\
\quad(\text { almA })\end{array}$ & $\begin{array}{l}\alpha \beta \\
\text { monooxygenase } \\
\text { FAD } \\
\text { NAD }(\mathrm{P}) \mathrm{H}\end{array}$ & $\mathrm{C}_{22}$ to $\mathrm{C}_{36}$ & $\begin{array}{l}\text { Acinetobacter sp. } \\
\text { (Wentzel et al. 2007) } \\
\text { Alcanivorax, Marinobacter, Salinisphaera \& } \\
\text { Parvibaculum, } \\
\text { (Wang \& Shao 2012). } \\
\text { Pseudomonas aeruginosa } \\
\text { (Liu et al. 2014) }\end{array}$ \\
\hline $\begin{array}{l}\text { Flavin-dependent } \\
\text { monooxygenases } \\
(\text { ladA) }\end{array}$ & $\begin{array}{l}\alpha \beta \text { external oxygenase } \\
\text { FMN / NAD }(\mathrm{P}) \mathrm{H}\end{array}$ & $\mathrm{C}_{15}$ to $\mathrm{C}_{36}$ & $\begin{array}{l}\text { Geobacillus thermodenitrificans } \\
\text { (Wang et al. 2006) }\end{array}$ \\
\hline $\begin{array}{l}\text { Copper-containing } \\
\text { monooxygenases } \\
\text { (pMMO) }\end{array}$ & $\begin{array}{l}\alpha \beta \gamma \text { hydroxylase; copper, } \\
\text { iron } \\
\text { Quinone reductase: FAD, } \\
\text { NADH }\end{array}$ & $\mathrm{C}_{1}$ to $\mathrm{C}_{5}$ & $\begin{array}{l}\text { Methylococcus, Methylosinus, Methylocystis, } \\
\text { Methylobacter, } \\
\text { Methylomicrobium } \\
\text { (McDonald et al. 2006) } \\
\text { Methylocystis echinoides } \\
\text { (Pieja et al. 2011) }\end{array}$ \\
\hline $\begin{array}{l}\text { Soluble diiron } \\
\text { monooxygenases } \\
(\text { sMMO })\end{array}$ & $\begin{array}{l}\alpha 2 \beta 2 \gamma 2 \quad \text { hydroxylase; } \\
\text { binuclear iron reductase, } \\
{[2 \mathrm{Fe}-2 \mathrm{~S}], \mathrm{FAD}, \mathrm{NADH}} \\
\text { regulatory subunit }\end{array}$ & $\mathrm{C}_{1}$ to $\mathrm{C}_{8}$ & $\begin{array}{l}\text { M. capsulatus (Bath) } \\
\text { (Green \& Dalton 1989) } \\
\text { Methylocystis sp. strain M } \\
\text { (Nakajima et al. 1992), and } \\
\text { M. trichosporium OB3b } \\
\text { (Fox et al. 1989) }\end{array}$ \\
\hline
\end{tabular}


Table 2. Aromatic hydrocarbon degrading dioxygenases

\begin{tabular}{|c|c|c|c|}
\hline $\begin{array}{c}\text { Enzyme } \\
\text { system }\end{array}$ & $\begin{array}{l}\text { Composition } \\
\text { and cofactors }\end{array}$ & Substrate range & Strain, gene and reference \\
\hline $\begin{array}{c}\text { Type III } \\
\text { naphthalene } \\
\text { dioxygenase } \\
\text { and PAH } \\
\text { dioxygenases }\end{array}$ & $\begin{array}{l}\alpha 3 \beta 3 \\
\text { oxygenase } \\
\text { FNR }_{\mathrm{N}} \text {-type } \\
\text { reductase } \\
{[2 \mathrm{Fe}-2 \mathrm{~S}] \text {-type }} \\
\text { ferredoxin }\end{array}$ & $\begin{array}{l}\text { Low-MW PAH } \\
\text { (naphthalene, } \\
\text { phenanthrene } \\
\text { and anthracene) }\end{array}$ & $\begin{array}{l}\text { Pseudomonas sp. NCIB9816-4 (ndo) } \\
\text { (Kauppi et al. 1998) } \\
\text { Pseudomonas putida G7 (nah) } \\
\text { (Simon et al. 1993) } \\
\text { Comamonas testeroni GZ42 (phn) } \\
\text { (Goyal \& Zylstra 1996) } \\
\text { Burkholderia sp. RP007, (phn) } \\
\text { (Laurie \& Lloyd-Jones 1999) } \\
\text { Ralstonia sp. U2 (nag) } \\
\text { (Zhou et al. 2001) } \\
\text { Polaromonas naphthalenivorans CJ2 (nag) } \\
\text { (Jeon et al. 2006) } \\
\text { Alcaligenes faecalis AFK2 (phn) } \\
\text { (Kiyohara et al. 1982) } \\
\text { Acidovorax NA3 (phn) } \\
\text { (Singleton et al. 2009). }\end{array}$ \\
\hline $\begin{array}{c}\text { Type IV } \\
\text { toluene } \\
\text { dioxygenase } \\
\text { and biphenyl } \\
\text { dioxygenase }\end{array}$ & $\begin{array}{l}\alpha 3 \beta 3 \\
\text { oxygenase } \\
\text { GR-type } \\
\text { reductase } \\
{[2 \mathrm{Fe}-2 \mathrm{~S}] \text {-type }} \\
\text { ferredoxin }\end{array}$ & $\begin{array}{l}\text { BTEX, biphenyl, } \\
\text { naphthalene, } \\
\text { fluorene, } \\
\text { phenanthrene } \\
\text { and pyrene }\end{array}$ & $\begin{array}{l}\text { Pseudomonas putida F1 (tol) } \\
\text { (Zylstra \& Gibson 1989) } \\
\text { Pseudomonas pseudoalcaligenes KF707(bph) } \\
\text { (Furukawa \& Miyazaki 1986) } \\
\text { Burkholderia xenovorans. LB400 (bph) } \\
\text { (Mondello 1989) } \\
\text { Rhodococcus sp. RHA1 (bph) } \\
\text { (Furusawa et al. 2004) } \\
\text { Sphingobium yanoikuyae B1 (bph) } \\
\text { (Ferraro et al. 2007) } \\
\text { Sphingomonas CHY-1(bph) } \\
\text { (Jakoncic et al. 2007) } \\
\text { Novosphingobium pentaromativorans sp. nov.(bph) } \\
\text { (Sohn et al. 2004) }\end{array}$ \\
\hline $\begin{array}{c}\text { Type V } \\
\text { phenanthrene } \\
\text { and phthalate } \\
\text { dioxygenase }\end{array}$ & $\begin{array}{l}\alpha 3 \beta 3 \\
\text { oxygenase, } \\
\text { GR-type } \\
\text { reductase } \\
\text { [3Fe-4S]-type } \\
\text { ferredoxin }\end{array}$ & $\begin{array}{c}\text { phenanthrene } \\
\text { and high-MW } \\
\text { PAH }\end{array}$ & $\begin{array}{l}\text { Nocardioides sp. KP7 (phd) } \\
\text { (Saito et al. 1999) } \\
\text { Mycobacterium vanbaalenii PYR-1 (pht) } \\
\text { (Kim et al. 2007) } \\
\text { Mycobacterium sp. (pht) 6PY1 } \\
\text { (Krivobok et al. 2003) } \\
\text { Terrabacter sp. strain DBF63 (pht) } \\
\text { (Habe et al. 2003) } \\
\text { Rhodococcus sp. UW1 (pht) } \\
\text { (Walter et al. 1991) }\end{array}$ \\
\hline
\end{tabular}

\section{Glossary}

Alkanes. Saturated hydrocarbons, they can be linear (n-alkanes), cyclic (cyclo-alkanes) or branched (iso-alkanes) (Wentzel et al. 2007)

Biodegradation. Process by which organic substances are broken down by enzymes produced by living microbial organisms (mainly by aerobic bacteria but also reported under anaerobic conditions) into simpler substances such as carbon dioxide, water and ammonia (OECD, 1997).

Hydroxylases. Group of enzymes that catalyze oxidation reactions in which one of the two atoms of molecular oxygen is incorporated into the substrate and the other is used to oxidize NADH or NADPH (Massart \& Vercauteren 1959).

Metatranscriptomics. Science that studies gene expression profiling of complex microbial communities within natural environments (Aguiar-Pulido et al. 2016).

Metabolomics. Science of chemical processes involving metabolites, the small molecule intermediates and products of metabolism in a biological system (Aguiar-Pulido et al. 2016).

Microbial communities. Multi-species assemblages, in which organisms live together in a contiguous environment and interact with each other (Boon et al. 2014; Konopka 2009).

Microbial bioremediation. Technology treatment of naturally occurring organisms and their products in 
different biotechnological applications to break down hazardous substances into less toxic or non-toxic substances (Vitorino \& Bessa 2017)

Petroleum hydrocarbons. Organic compounds from oil that contain only carbon and hydrogen (Atlas, 1981).

PAHs. Polycyclic aromatic hydrocarbons are a group of chemicals that contain two or more fused aromatic rings in linear, angular, or cluster arrangements (Cerniglia 1992).

Proteomics. Large-scale study of proteins in a biological system aimed at understanding of gene function (Pandey \& Mann 2000).

RHO and RHD. Rieske, non-heme iron-type aromatic ring-hydroxylating oxygenases are multicomponent enzymes that catalyze the insertion of molecular oxygen into benzene rings, a common first step in the bacterial degradation of aromatic compounds. They can be monooxygenases (RHO) or dioxygenases (RHD) when one or both atoms of dioxygen are inserted into the substrate, respectively (Ferraro et al. 2005). 